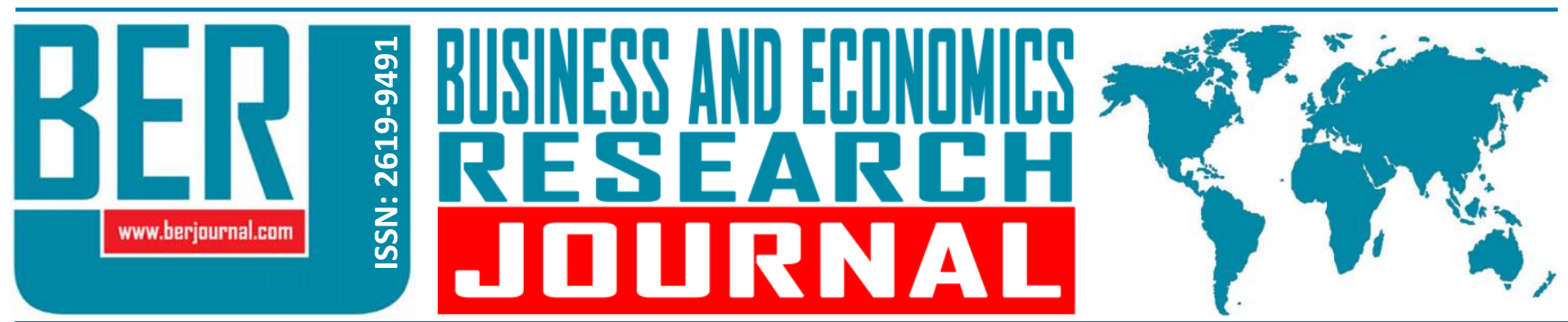

Business and Economics Research Journal Vol. 10, No. 1, 2019, pp. 55-75 doi: 10.20409/berj.2018.151

\title{
BİST Endekslerinin Şoklara Kısa-Dönemli Tepkisi: Bir Makro Analiz
}

\author{
Ali Ulvi Ozgul ${ }^{\text {a }}$, Ibrahim Korkmaz Kahraman ${ }^{\mathrm{b}}$
}

Öz: Hisse senetlerine odaklı, mikro ölçekte yürütülen De Bondt ve Thaler'in (1985) klasik aşırı tepki hipotezine yönelik yaklaşımının aksine endeksler veri alınarak yapılan bu çalışmada piyasanın ve endekslerle temsil edilen portföy gruplarının şoklara tepkisinin analiz edilmesi amaçlanmıştır. Şok filtreleme yönteminde, Lasfer vd.'nin (2003) önerdikleri bir gözlemin 60 gün öncesinden 11 gün öncesine değin gözlemleri kapsayan 50 günlük pencere esas alınmış, volatilite ise Üstel Ağırlıklı Hareketli Ortalama (EWMA) yöntemi ile tahmin edilmiştir. Şoklar için farklı bir eşiğin kullanıldığı çalışma sonucunda şok günündeki tepkileri birbirine yakın ve anlamlı olarak farklılaşan endeksler belirlenmiştir. Iki dönem halinde yapılan analizde, 2000-2008 dönemi için, XUSIN endeksi dışında, endekslere yönelik referans çalışmalara benzer şekilde düşük tepkiyi gösteren bulgular tespit edilmiştir. Ancak bu sonuç, sadece pozitif şoklar için geçerlidir. lyi haberlere yönelik bu temkinli davranış, ikinci dönemde (2009-2018) kaybolmaktadır. Bu değişim, bilgi etkinliği bakımından piyasamızın geliştiğinin bir göstergesi olarak değerlendirilebilir. Genel itibariyle endekslerin şoklara, anlamlı olarak aşırı ya da düşük tepki vermediğini ortaya koyan çalışma, tepkinin tam ve zamanında gerçekleştiğini savunan Etkin Piyasalar Hipotezi (EPH) ile uyumlu sonuçlar vermektedir.

\section{Anahtar Sözcükler: Davranışsal Finans, Aşırı Tepki Hipotezi, Düşük Tepki Hipotezi, Etkin Piyasalar Hipotezi, EWMA Filtrelemesi \\ JEL: G10, G14, G30, G40

$\begin{array}{ll}\text { Geliş } & : \text { 15 Ekim } 2018 \\ \text { Düzeltme } & : \text { 30 Ekim } 2018 \\ \text { Kabul } & : \text { 05 Kasım 2018 } \\ & \\ \text { Tür } & \text { : Araştırma }\end{array}$

\section{Short-Term Reaction of BİST Indexes to Shocks: A Macro Analysis}

Abstract: This research, which takes stock market index data as input in contrast to De Bondt and Thaler's (1985) classical approach for testing overreaction hypothesis on a micro scale via individual stocks, is aimed at analyzing reactions of the market in aggregate and portfolio groups, which are represented by indexes. The shock-filtering procedure is based on 50-day window, encompassing observations from 60 days to 11 days prior to an observation as suggested by Lasfer et al. (2003) while volatility has been estimated through Exponentially Weighted Moving Average (EWMA) method. Indexes resembling each other and significantly differing from others in terms of their reaction on the day of shocks, which are detected by a different threshold have been determined. The analysis implemented separately for two subperiods outputs findings which support the validity of underreaction on all indexes except XUSIN within 2000-2008, in line with the reference researches on indexes. This result is, however valid only for positive shocks. The cautious behavior against good news disappears in the second subperiod (2009-2018). This variation can be regarded as a sign of our market's progress in terms of information efficiency. Putting forth no significant over or underreaction of indexes to shocks, this paper shows results in compatible with the Efficient Market Hypothesis (EMH) which asserts just and timely reactions to shocks.
Keywords: Behavioral Finance, Overreaction Hypothesis, Underreaction Hypothesis, Efficient Market Hypothesis, EWMA Filtering

JEL: G10, G14, G30, G40

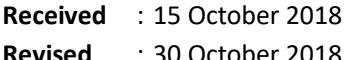

Accepted : 05 November 2018

Type : Research

PhD., Independent Researcher, Denizli, Turkiye, ulviozgul@uydunet.net (ORCID ID: 0000-0002-1082-2652)

b PhD., Lecturer, Pamukkale University, Cal Vocational High School, Denizli, Turkiye, ikahraman@ pau.edu.tr (ORCID ID: 0000-00015083-3586) 


\section{Giriş}

Piyasalarda gözlenen şoklar ve bunları takiben gerçekleşen fiyat hareketleri, yoğun bir şekilde araştırılmakta ve anlamlandırılmaya çalışılmaktadır. Şokların kısa ve uzun dönemli etkileri, şirketlerin performansının önemli bir göstergesi olan şirket değerinin artması ya da azalması ile sınırlı kalmamaktadır. Piyasanın aracı olduğu fon değiş tokuşunda ortaya çıkabilen risk-getiri asimetrisi ya da uyumsuzluğu, daha geniş ölçekte geçerli olan önemli etkiler arasındadır. Şoklara karşı piyasanın tepkiselliği, başta bilgiyle alakalı olanlar olmak üzere farklı değişkenler içeren yaklaşımlarla anlamlandırılmaya çalışılmaktadır. Bu çalışmada Borsa İstanbul'un (BiST) temel endekslerinden BiST Tüm (XUTUM), BiST 100 (XU100), BiST 50 (XU050), BiST 30 (XU030), BiST Sınai (XUSIN), BiST Mali (XUMAL), BIST Banka (XBANK), BIST Holding (XHOLD), BiST Tüm-100 (XTUMY) ve BIST 100-30 (XYUZO) alınarak, öne çıkan yaklaşımlar çerçevesinde BíST’te gözlenen tepkiselliğin mercek altına alınması amaçlanmıştır.

Endeksler üzerinden gözlenen piyasa tepkisini konu edinen çalışmalarda, örneğin Schnusenberg ve Madura (2001), Lasfer vd. (2003) ve Spyrou vd. (2007), hisse senetleri bazında yürütülen araştırmalardan farklı olarak öncelikle şoklar tespit edilmekte ve gerçekleşen şoklar sonrasında yatıımcıların şoklara verdiği tepkiler analiz edilmektedir. Yatırımcıların genel itibariyle şoklara verdiği tepkileri en yalın haliyle üç hipotez ile açıklamak mümkündür. Spyrou vd. (2007), bu üç hipotezi "Etkin Piyasalar Hipotezi" (EPH), "Aşırı Tepki Hipotezi" (ATH) ve "Düşük Tepki Hipotezi" (DTH) olarak sıralamaktadır.

Fama'nın (1970) öne sürdüğü EPH, piyasa tepkisi konusunda en temel fikri altyapıyı oluşturmaktadır. Kaynak tahsisi için doğru sinyalleri sağlayan fiyatların oluştuğu piyasalar, ideal durumu temsil etmektedir. Yatırımcılar, ait oldukları şirketin tüm faaliyetlerine sahip olmayı ifade eden hisse senetleri arasında seçim yaparken fiyatların herhangi bir anda mevcut tüm bilgileri "tam olarak yansıttığı" varsayımı altında hareket ederler. Bünyesinde oluşan fiyatların mevcut bilgiyi her zaman "tam olarak yansıttığı" piyasalar, etkindir (Fama, 1970:383). Etkin piyasalarda şoka neden olan yeni bilgi fiyata tam olarak ve zamanında yansıyacağından sonrasında aşırı ya da düşük tepkiden söz edilemez. Hipotezin önemli bir önermesi, fiyat hareketlerinde belirli bir örüntünün geçerli olamayacağına yöneliktir. Rassal yürüyüş, orijinal makalede de ifade edildiği gibi bu önermeyi, dolayısıyla hipotezi simgelemektedir.

Yeni bilgiye tam ve yerinde tepkiyi ifade eden $\mathrm{EPH}^{\prime}$ nin aksine tepkinin aşırı yönde gerçekleştiğini savunan ATH'ye göre, şoku takiben piyasada tersi yönde hareketlerle düzeltmeler gerçekleşmektedir. Hipotez, De Bondt ve Thaler'in piyasalara yönelik, literatür özetinde değinilen ampirik uygulaması ile birlikte insan davranışının finansa yansımalarını açığa çıkarmıştır. Çalışmanın insan psikolojisini esas alan fikri alt yapısı, Bayes kuralının bireylerin yeni veriye nasıl tepki verdiklerini tasvir edemediğini öne süren Kahneman ve Tversky'e dayanmaktadır. Insanlar, tahminlerini güncellerken yakın zamanlı bilgiye daha fazla ağılık vermekte ve önceye ait baz veriyi gereğinden az ağırlıklandırmaktadır. Tahminlerde, izlenimlerle ya da kanaatlerle yapılan konumlandırma, dağılım ile yapılan konumlandırmanın önüne geçmektedir (Kahneman ve Tversky, 1977:3-1).

EPH'den ATH'nin tersi yönünde uzaklaşmayı ifade eden DTH ise, piyasa oyuncularının yeni bilgiye olması gerekenden daha az tepki verdiğini öne sürmektedir. Dolayısıyla, izleyen dönemde yeni bilginin neden olduğu fiyat değişimi ile aynı yönde fiyat hareketlerinin gerçekleşmesi beklenir. Fama (1998), tepkinin ${ }^{1}$, dolayısıyla getirinin pozitif olması durumunda, pozitif getirilerin devamını ifade eden momentum kavramını Jegadeesh ve Titman'a (1993) dayandırmaktadır. ATH'nin geçerli olduğu durumda momentum, negatif şoklar sonrasında devam eden negatif getirilerle de geçerli olacaktır. Diğer yandan Fama (1998), EPH'nin öne sürülmesini takip eden yaklaşık 30 yıl boyunca hipoteze aykırı ampirik çalışma bulgularını değerlendirdiği makalesinde, bilgiye yönelik belirgin aşırı tepkinin, düşük tepki ile neredeyse aynı oranda gözlendiğini iddia etmektedir.

Bölüm girişinde ifade edilen amaç doğrultusunda çalışma, yararlanılan ve çalışmamıza yön veren çalışmaların özeti ve veri seti ile metodolojinin ele alındığı bölümler ile ilerleyecektir. Takiben uygulamamıza yönelik açıklamalar ve elde edilen bulgular, ayrı bir bölümde sunulacaktır. Bulgular, son bölümde değerlendirilerek çalışmanın sonucu özetlenecek, ayrıca bu bölümde ileride yapılacak araştırmalar için önerilere yer verilecektir. 


\section{Literatür Özeti}

Üç temel hipotezin test edilmesine yönelik çalışmalar, ağırlıklı olarak hisse senedi bazında yürütülmektedir. Portföy oluşturma döneminde geçerli olan bu yaklaşımla, kazanan ve kaybeden hisselere dayalı olarak portföyler oluşturulmakta ve sonrasında piyasanın tepkileri teori kapsamında değerlendirilmektedir. EPH'den sapmaları ifade eden piyasa anomalileri de bu bağlamda incelenerek gerek fiyat hareketlerindeki örüntü gerekse insan davranışına yönelik ilave teorik katkı sağlanmaktadır. Hisse bazlı klasik yaklaşımı temel alan literatür özetini takiben endekslere dayalı çalışmalar özetlenecektir.

\subsection{Hisse Senedi Bazlı Yaklaşımı Esas Alan Çalışmalar}

De Bondt ve Thaler $(1985,1987)$, yatırımcıların beklenmedik haberlere aşırı tepki gösterme eğiliminde olup olmadığını araştırmak amacıyla Ocak 1926 ile Aralık 1982 dönemi New York Borsası (NYSE) aylık getiri verilerini kullanmışlardır. Elde edilen sonuçlar, kaybedenlerin kazananlara göre çok daha yüksek olmak üzere aşırı tepki gösterdiklerini ve aşırı getirilerin çoğunun ocak ayında gerçekleştiğini göstermektedir. Ayrıca, yatırımcıların kısa vadeli kazanç elde etmek amacıyla daha yüksek aşırı tepki verdiklerini tespit etmişlerdir. De Bondt ve Thaler'in elde etmiş olduğu bu sonuçlar göstermektedir ki; yatırımcıların, geçmiş dönemde kaybeden hisse senetlerini satın alarak ve aynı şekilde geçmiş dönemde kazandıran hisse senetlerini satarak piyasanın üzerinde anormal getiri sağlama olanağı bulunmaktadır.

Alonso ve Rubio (1990), İspanya'da ATH'yi test etmek amacıyla yapmış oldukları çalışmada, De Bondt ve Thaler'e benzer şekilde kazandıran ve kaybettiren portföyleri oluşturmuşlardır. Çalışma sonucunda, portföy oluşturma dönemini takip eden 12 aylık dönemde kaybettiren portföylerin, kazandıran portföylere göre \%24,5 daha fazla getiri sağladığını tespit etmişlerdir.

Bowman ve Iverson (1998), Yeni Zelanda Borsasına yönelik 1967 ile 1980 yılları arasındaki dönemi kapsayan çalışmalarında haftalık getiriler kullanarak $A T H$ 'nin geçerli olduğunu tespit etmişlerdir. Çalışmada fiyat değişimlerinin fiyat düşüşlerinden sonra daha yoğun bir şekilde yaşandığı ve fiyat değişimi ne kadar büyük olursa, takip eden dönemde fiyat düzeltmesinin de o derece büyük olduğu sonucuna ulaşmışlardır.

Fung (1999), De Bondt ve Thaler araştırması ile mutad hale gelen metodolojiyi kullanmak üzere Hong Kong Borsa'sında yer alan Hang Seng endeksini oluşturan 33 hisse senedinden kazanan ve kaybedenler portföylerini oluşturmuştur. Çalışmada portföy oluşturma dönemi olarak iki yıl, test dönemi olarak ise bir yıllık veriler kullanılmıştır. Elde edilen sonuçlara göre; portföy oluşturma dönemini takip eden bir yıl sonunda kaybeden portföyünün kazanan portföyde yer alan hisse senetlerine göre $\% 9,9$ fazla kazandırdığını ve sonuç olarak Hong Kong Borsasında ATH'nin geçerli olduğunu tespit etmiştir.

Baytaş ve Çakıcı (1999), çalışmada yedi ülkenin (ABD, Kanada, İngiltere, Japonya, Almanya, Fransa ve İtalya) borsaları için 1982 ile 1991 yılları arasında ATH'yi test etmişlerdir. Bu amaçla kazanan ve kaybeden portföyler oluşturulmuştur. Çalışmanın sonucunda İngiltere, Japonya, Almanya, Fransa ve İtalya borsalarında oluşturulan kaybeden portföyünün piyasaya göre daha yüksek getiri elde edildiği tespit edilmiştir.

Gaunt (2000), yapmış olduğu çalışmada Avustralya Borsasında 1974-1997 döneminde yer alan hisse senetlerine ait fiyat hareketlerini incelemiş ve ATH'nin geçerli olduğu sonucuna ulaşmıştır. Ayrıca, kaybettiren portföylerin içerisinde yer alan küçük firmaların daha yüksek getiri sağladığı tespit edilmiştir.

Karan ve Tarım (2001), çalışmalarında 1 Ocak 1990 ile 30 Haziran 1999 arası çift seans uygulamasının başladığı dönemin öncesini ve sonrasını ayrı ayrı değerlendirilerek fiyat limitlerinden kaynaklanan farkılı̆̆ı ATH açısından araştırmışlardır. Elde edilen sonuçlara göre, pozitif yönde fiyat limitine ulaşan hisse senetleri için çift seans uygulamasının başlaması ile güçlü bir aşırı tepkinin varlı̆ıı tespit edilmiştir.

Huang, Fu ve Ke (2001), 1990 ile 1996 yılları arasında Tayvan Borsasındaki günlük verileri kullanarak yapmış oldukları çalışmada ATH'nin geçerli olduğu sonucuna ulaşmışlardır. Nam, Pyun ve Avard (2001), 19261997 yılları arası verileri kullanarak yapmış oldukları çalışmada ATH'nin geçerli olduğu ve oluşturulan kaybeden portföylerin fiyat değişimlerinin daha hızlı olduğu sonucuna ulaşmışlardır. 
Fung ve Lam (2004), Hong Kong Borsasında işlem gören endeks futures sözleşmelerinde ATH'nin geçerliliğini araştırmışlardır. Yazarlar, endekse dayalı futures piyasasında aşırı tepkinin, sözleşmelerdeki (gerçeğe uygun değerlerine referansla) fiyatlama hataları kullanılarak sınanabileceğini ortaya koymuşlardır. Sözleşmeleri, fiyatlandırma hatalarının negatif olduğu günlerde satın almanın, fiyatlandırma hatasının pozitif olduğu günlerde almaya göre daha yüksek getiri sağladığı tespit edilmiştir.

Chiao ve Hueng (2005), 1975-1999 yılları arası veriler kullanarak yapmış oldukları çalışmada Tokyo Borsası'nda ATH'nin geçerli olduğunu tespit etmişlerdir. Antoniou, Galaritos ve Spyrou (2005), 1990 ile 2000 yılları arasında Atina Borsası'nda ATH'yi destekler sonuçlara ulaşmışlar ve zıtılık stratejilerinin anormal getiri elde etmede yararlı olduğunu tespit etmişlerdir.

Sevim, Yıldız ve Akkoç (2007), 1 Ocak 1988 ile 31 Aralık 2002 tarihleri arasındaki dönemi inceledikleri çalışmada, 36 aydan oluşan 4 periyot oluşturarak Borsa İstanbul'da ATH'yi test etmişlerdir. Elde edilen sonuçlara göre oluşturulmuş olan kazandıran portföylerden piyasanın altında \%50,57 oranında daha az getiri elde edildiğini, kaybettiren portföylerden ise piyasanın üzerinde $\% 66,11$ daha fazla getiri sağlandığını tespit etmişlerdir.

Parikakis ve Syriopoulos (2008), çalışmalarında gelişmekte olan iki ülke (Türkiye ve Brezilya) ve gelişmiş iki ülkenin ( $A B D$ ve İngiltere) döviz kurları için bir günlük dalgalanmalarının ardından ATH'yi test etmişlerdir. ABD Doları, Türk Lirası ve Brezilya Realinde aşırı tepkinin varlığını tespit etmişler, İngiliz Sterlininde ise aşırı tepkinin olmadığı sonucuna ulaşmışlardır.

Barak (2008), Borsa İstanbul'da uzun dönem ATH'yi ölçmek amacıyla Ocak 1992-Aralık 2004 dönemi verilerini kullandığı çalışmasında 5 yıllık kazanan/kaybeden portföyleri oluşturmuştur. Elde edilen sonuçlara göre geçmişte kazandıran hisse senetlerinden oluşan portföylerin takip eden dönemde kaybettirdiği veya daha az kazandırdığı; kaybettiren portföylerin ise takip eden dönemde kazandırdığı tespit edilmiştir. Çalışma sonuçları Borsa İstanbul'da ATH'nin geçerli olduğunu göstermektedir.

Aguiar ve Sales (2010), 1999-2007 dönemi arasında petrol, mali endeksler, tekstil, gaz ve demir işkollarında yer alan şirketlerin hisse senetleri açısından ATH'yi araştırmışlardır. Elde edilen sonuçlar, bir yatırımcının kazanan portföyünde yer alan hisse senetlerini satması ve kaybeden portföyünde yer alan hisse senetlerinden satın alması neticesinde anormal getiriler elde edilebildiğini göstermektedir.

Doğukanlı ve Ergün (2011), yapmış oldukları çalışmada birer yıllık portföy ve test dönemleri oluşturmuşlardır. BIST 100, BIST 50, BIST 30, BIST Sınai ve BIST Mali Endeksine dahil olan, Temmuz 1998 ve Haziran 2008 arasında işlem görmüş hisse senetlerini veri seti olarak kullanmışlar, yapılan analizler sonucunda BiST 30 endeksi dışındaki endekslerde ATH'yi destekler sonuçlara ulaşmışlardır. Çalışma, endeks temelli yaklaşımdan ziyade kazanan/kaybeden portföy oluşturma ve sonrasında tepkileri test etmeye yöneliktir.

Doğukanlı, Vural ve Ergün (2012), Borsa İstanbul'da anormal getiri elde etmek amacıyla zıt yatırım stratejilerinin yararlı olup olmadığını ve ATH'nin geçerliliğini araştırmışlardır. Çalışmada zıt yatırım stratejisinin ve ATH'nin geçerli olduğunu destekler sonuçlara ulaşmışlardır.

Klößner, Becker ve Friedmann (2012), hisse senedi fiyatındaki değişimlere aşırı tepki vermeye neden olan haberlerin etkisinin ölçülmesi amacıyla bir model geliştirmişlerdir. Bu model, yukarı yönlü ve aşağı yönlü aşırı tepkiyi test etmek için kullanılmaktadır. Özellikle kötü haberlere karşı, gün içi aşırı tepki için satın alma işleminin performansı analiz edilmektedir.

Tunçel (2013), çalışmasında Ocak 1998-Aralık 2012 döneminde 146 hisse senedinin aylık getirilerini kullanmıştır. Aylık getiri serilerinin kapsadığı dönemi dikkate alarak 36 aydan oluşan 4 ayrı periyot oluşturmuştur. Kaybeden portföyün aylık ortalama kümülatif anormal getirisi - $\% 1,07$ 'den, $\% 2,728$ artışla \%1,658'e çıkmıştır. Benzer şekilde kazanan portföyün aylık ortalama kümülatif anormal getirisi \%5,951'den, \%4,754 azalışla \%1,197 olarak gerçekleşmiştir. Bu bulgular Borsa İstanbul'da ATH'nin varlığını desteklemektedir.

Ali, Talib, Nassir ve Abidin (2013), Ocak 1990 ile Aralık 2009 dönemi arasında Malezya Borsası'nda yer alan firmaların hisse senedi getirileri ile firma büyüklüğü arasındaki ilişkiyi göz önüne alarak ATH'yi 
araştırmışlardır. Elde edilen sonuçlar hem kazanan hem de kaybeden portföylerinde geri dönüş davranışı yaşandığını ve firma büyüklüğü düzeltmesinden sonra, test döneminde kaybeden portföylerin kazanan portföylere göre daha yüksek getiri sağladığını göstermektedir.

Chaouachi ve Douagi (2014), çalışmalarında Tunus Borsası'nda ATH'nin varlığını test etmek amacıyla üç yıllık kazanan ve kaybeden portföyler oluşturmuşlardır. Kaybeden portföylerin takip eden üç yılda daha iyi performans sergilediği sonucuna ulaşmışlardır.

Caporale, Gil-Alana ve Plastun (2015), 2002 ile 2014 yılı sonuna kadar olan dönemde ABD borsası, 10 para birimi, altın ve petrol fiyatlarını kullanarak haftalık ve aylık getirileri kullanarak ATH'yi test etmişlerdir. Elde edilen sonuçlara göre ise haftalık verilerin aylık verilere göre ağırlıklı olarak daha fazla aşırı tepki gösterdiğini destekler sonuçlar elde etmişlerdir.

Baubaker, Farag ve Nguyen (2015), çalışmada Mısır Borsasında gerçekleşen olayların kısa vadede aşırı tepkilere neden olup olmadığını araştırmışlardır. Kötü haberlerden kaybedenler portföyü, iyi haberlerden ise kazananlar portföyü oluşturulmuştur. Yatırımcılar, kazanan portföylerini satarak ve kaybeden portföyleri satın alarak anormal getiri elde etmektedirler. Çalışmada ayrıca Orta Doğu bölgesindeki gerginlikler nedeniyle olaylardan sonraki üç gün boyunca negatif anormal getiri elde edilmiş, ardından dördüncü günden itibaren fiyatlarda düzeltmeler meydana gelmiştir. Bunun yanı sıra bulgular, küçük firmaların büyük firmalara göre daha fazla tepki verdiğini göstermektedir.

Dizdarlar ve Can (2017), 2003 yılı ile 2016 döneminde BiST 100 endeksinde yer alan şirketler için OcakAralık, Haziran-Mayıs ve Ağustos-Temmuz dönemleri için ATH'nin geçerli olup olmadığını araştırmışlardır. Bu amaçla kümülatif anormal getiriler hesaplanmış ve t testi kullanılmıştır. Elde edilen sonuçlara göre Borsa İstanbul'da ATH'yi destekler sonuçlar elde edilememiştir.

Blackburn ve Cakici (2017), çalışmada 1993 ile 2014 yılları arasında Kuzey Amerika, Avrupa, Japonya ve Asya bölgelerinde yer alan yirmi üç gelişmiş ülkenin getirilerini incelemişlerdir. Çalışma sonucunda son üç yıl içinde kaybettiren hisse senetleri ile son üç yıldaki kazandıran hisse senetleri arasında pozitif getiri farkı olduğunu tespit etmişlerdir.

Caporale, Gil-Alana ve Plastun (2018), çalışmada Dow Jones endeksi ve bu endekse dahil Microsoft ve Boeing hisse senetleri, EUR/USD, USD/JPY ve GBF/CHF döviz kurları ve emtiadan ise Altın ve Yağ fiyatlarının Ocak 2002'den Eylül 2014'e kadar günlük fiyat serileri ile kısa vadeli aşırı tepkinin olup olmadığını test etmişlerdir. Elde edilen sonuçlar aşırı tepkilerin varlığını teyit etmektedir. Ayrıca sonuçlar, aşırı tepkiler sonrası zıtlık stratejisinin döviz kuru ve emtia piyasalarında kar üretmediğini; ancak ABD borsalarında karlı olabileceğini göstermiştir.

Kashif, Saad, Chhapra ve Ahmet (2018) çalışmada De Bondt ve Thaler (1985)'in yapmış oldukları çalışmaya uyumlu olarak, kümülatif anormal getiriler kullanarak Pakistan'da Karachi Borsası (KSE) üzerindeki ATH'yi incelemişlerdir. Elde edilen sonuçlar ATH'yi destekler niteliktedir.

Çalışmaların geneli dikkate alındığında, piyasa ve dönem bazında birkaç istisna hariç tutulursa, ATH'nin hisse senedi piyasalarında geçerli olduğuna dair sonuçlar elde edilmiştir. ATH'yi destekleyen bulgulara, test döneminde kazandıran/kaybettiren portföyler oluşturulmasını takiben portföy performanslarının izlenmesi ile ulaşılmaktadır. Portföy oluşturma dönemi uzunluğu ise De Bondt ve Thaler (1985) çalışmasında olduğu gibi bir yıldan beş yıla kadar değişkenlik göstermektedir. Bireysel yatırımcıların perspektifinden değerlendirildiğinde, bu süre uzundur. Ayrıca, kazandıran/kaybettiren portföylerin oluşturulma yöntemi, tekil olarak hisse senetlerinin performanslarının izlenmesini ve kayıt altına alınmasını gerekli kılmaktadır. Uzmanlık gerektiren yöntemin uygulanması, bir çok yatırımcı için mümkün görünmemektedir. Bu bağlamda, ATH'nin mikro ölçekte ve dar kapsamda geçerli olduğu belirtilebilir. Mikro ölçek ile belirtilmek istenen, ATH'nin açığa çıkardığı, anormal getiri sağlamaya yönelik zıtık stratejisinin hisse senetlerinin tekil olarak ele alınmasına dayalı olmasıdır. Diğer yandan pasif yatırım stratejisini yeğleyen yatırımcılar, borsalar tarafından oluşturulan endeksleri izleyen yatırım fonlarına, ör. XU100 endeksini izleyen ticari banka fonlarına, yönelmektedir. Bu çerçevede, endeksler üzerinden EPH, ATH ve DTH'nin geçerliliğini 
araştırmayı amaç edinen çalışmamız, özetlenen çalışmalardan farklılaşmakta, makro ölçekte yatırımcı davranışına odaklanmaktadır.

\subsection{Endeks Verisine Dayanan Çalışmalar}

Schnusenberg ve Madura (2001), tekil olarak ya da kazanan/kaybeden grup bazında hisse senetlerindeki aşırı tepkiyi değerlendirmek yerine piyasanın (ya da sektörün) genel tepkisini değerlendirmeyi tercih etmişlerdir. Yazarlar, piyasa endekslerini kullanarak ilerledikleri bu yaklaşımla portföye dahil edilen hisse senetleri arasında farklı günlerde ortaya çıkan performans kaynaklı ve karmaşık etkisi olan kesitler arası farklılığın önlenebileceğini savunmaktadır. Kazanan/kaybeden portföyler bazında tepkiyi ölçmek yerine, aynı firmaların hisselerinden oluşan endekslerin en iyi ve en kötü performansa sahip olduğu günler referans alınarak piyasanın/sektörün genel tepkisi endekslerle ölçülebilmektedir. Çalışmada uzun dönemde gözlenen ortalamaya dönme olgusuna karşın endekslerin kısa dönemli getiri davranışına odaklanılmıştır. Hisse senedi piyasalarında kısa dönemli, örneğin günlük, aşırı/düşük tepki bulguları, ATH'ye yönelik daha sağlam kanıt oluşturmaktadır (Schnusenberg ve Madura, 2001:182). Endeks temelli çalışmaların özetinden önce bu alandaki temel çalışma olan Schnusenberg ve Madura (2001) araştırmasında yer verilen Belirsiz Bilgi Hipotezi $(\mathrm{BBH})$ ile endekslere özgü hipotezlere ana hatlarıyla değinilecektir.

BBH’ye göre yatırımcılar, iyi haberlere kıyasla kötü haberlere daha güçlü tepki göstermektedir. Bu davranış, yatırımcıların ihtiyat tarafında hata yapma temayülünde olmasından kaynaklanmaktadır. İhtiyat tarafında hata eğiliminin piyasaya yansıması, kötü haberlerde aşırı tepki, iyi haberlerde ise düşük tepki ya da hiç değilse tepkisizlik şeklinde ortaya çıkmaktadır. Dolayısıyla şoku takiben fiyatlarda geri dönüş, kaybedenler için anlamlı olarak pozitif olmalı, kazananlar için ise aynı kesinlikte olmasa da pozitif olmalı ya da hiç değilse negatif olmamalıdır (Schnusenberg ve Madura, 2001:186).

Endekslere yönelik hipotezlerden birincisi "Endeks Çeşitlendirmesi" hipotezidir. Schnusenberg ve Madura (2001); Brown, Harlow ve Tinic'in (1998) ve başkaca yazarların aşıı tepki anomalisini kısmen firma büyüklüğüne dayandırdıklarını belirtmektedir. Bu kapsamda, yazarlara göre ATH, hisseleri fazla takip edilmeyen, bu yüzden haklarında az bilgi üretilen küçük ölçekli şirketlerde daha yaygındır. Endekslerin genelde birbirine yakın büyüklükte şirketlerin hisselerinden teşkil edildiğine dikkat çeken Schnusenberg ve Madura'ya (2001) göre, aşırı tepkinin, piyasa değeri (kapitilizasyonu) bakımından küçük şirketlerin senetlerinden oluşan endekslerde görülmesi beklenir.

Schnusenberg ve Madura (2001), Cox ve Peterson'a (1994) dayandırdıkları "Likidite" hipotezini endeksler açısından değerlendirmişlerdir. Hipotez, günlük ve büyük ölçekte fiyat düşüşlerini aşırı satış baskısı ile ilişkilendirmektedir. Kapanış fiyatını belirleyen piyasa işlemi düşük alış fiyatından gerçekleşmektedir; sonrasında alış-satış makası ve düşen hisselere artan talep nedeniyle fiyatta geri dönüşler izlenmektedir. Hisse senedi sayısı fazla, dolayısıyla iyi çeşitlendirilmiş bir endeksin tepkiselliği için likidite hipotezinin açıklama gücü sınırlıdır. Ancak, daha az sayıda firmanın senetlerinden oluşan endekslerde bu hipotezin geçerli olması söz konusu olabilir.

Schnusenberg ve Madura (2001), çalışmalarında ABD'deki farklı borsaları geniş ölçekte temsil eden endekslerin günlük verilerini kullanmışlardır. Endeksler hesaplanmaya başlandığı tarihler itibariyle farklılaşmakla birlikte veri dönemi, en geniş haliyle 1928-1997 yıllarını kapsamaktadır. Kazanan/kaybeden günlerin (portföylerin) belirlenmesi için iki yaklaşım takip edilmiştir. Birincisi, geçmiş 60 günlük penceredeki ortalamaya dayalı beklenen değere dayanmaktadır. Beklenen değer, ikinci yaklaşımda ise ARIMA yöntemiyle tayin edilmektedir. Üstten ve alttan 10. yüzdelik dilime dahil olan günlere dayalı olarak kazanan/kaybeden portföyler belirlenmiştir. Analiz neticesinde altı endekste bir günlük düşük tepkinin geçerli olduğu raporlanmıştır. Yatırımcı psikolojisi açısından yapılan değerlendirmede aşırı yönde iyi haberlerin beklenene göre kötümser, aşırı yönde kötümser haberlerin ise, yine beklenene göre daha iyimser değerlendirildiği ifade edilmektedir. Kötü haberler için tepki süresi 60 güne kadar uzatıldığında BBH ile uyumlu bulgular elde edilmiştir. Altı endeks bazında genel olarak aynı yönde sağlanan kanıtların Etkin Piyasa Hipotezine de aykırı olduğu ileri sürülmüştür. 
Endekslere dayalı diğer bir çalışmada, Lasfer, Melnik ve Thomas (2003), 1989 ile 1998 yılları arasında 39 adet gelişmiş ve gelişmekte olan ülkenin günlük piyasa endekslerini kullanarak kısa vadeli fiyat davranışlarını incelemişlerdir. Çalışma kapsamındaki ülke borsalarında kısa vadede (10 güne kadar) pozitif fiyat dalgalanmalarını pozitif, negatif fiyat dalgalanmalarını ise negatif fiyat dalgalanmalarının takip ettiğini tespit etmişlerdir. Elde edilen sonuçlar, ATH ile tutarlı değildir. Araştırmacıların takip ettikleri yönteme izleyen bölümde değinilecektir.

Spyrou, Kassimatis ve Galariotis (2007), Aralık 1988'den Ocak 2004'e kadar olan dönemde, İngiltere hisse senedi piyasasında kısa vadede yatırımcıların fiyat hareketlerine tepkiselliğini araştırmışlardır. Ampirik analizde İngiltere'deki başlıca dört endeksin günlük kapanış fiyatları kullanıımıştır. Lasfer vd.'nin (2003) şok ayrıştırma yönteminin izlendiği çalışmaya göre, yüksek piyasa değerine (kapitilizasyonuna) sahip firmaların hisselerinden oluşan portföylerin şoklara karşı tepkisi, EPH ile uyumludur. Orta ve küçük kapitilizasyona sahip portföylerde ise, şok sonrası birkaç gün geçerli olan anlamlı düşük tepkinin varlığına ulaşılmıştır. Bu düşük tepki, risk faktörleri, takvim etkileri, alış-satış makası ve küresel kriz ile de açıklanamamaktadır.

Maher ve Parikh (2011), Hindistan borsasında farklı büyüklükteki şirket hisselerini temsil eden üç endeksin Nisan 2003-Haziran 2010 günlük verilerini kullandıkları çalışmalarında, diğer çalışmalardan farkı olarak şok öncesi birikimli getirileri de analiz etmişlerdir. Bu analiz, şok öncesinde bilgi kaçağının gerçekleşmediğini göstermektedir. Tepkilerin klasik t-testinin yanı sıra kukla değişken ve asimetrik GARCH modelinden yararlanılarak değerlendirildiği çalışma sonucunda piyasanın pozitif şoklara EPH ile uyumlu tepki verdiği saptanmıştır. Orta ve küçük büyüklükteki şirket hisselerinin yer aldığı iki endeks, 2008 krizi sonrası dönemde (01.04.2009-15.06.2010) geçerli olmamak kaydıyla, negatif şoklara ATH ile uyumlu tepki vermektedir. Belirtilen kriz sonrası dönemde ise piyasanın olumsuz haberlere aşırı tepki verdiği tespit edilmiştir.

Rezvanian, Krysiak ve Klaczynska (2015), yatırımcıların şoklara tepkisini Polonya'daki WIG ve WIG20 borsa endeksleri günlük kapanış değerlerini kullanarak incelemişlerdir. WIG verisi, Nisan 1991'den; WIG20 verisi ise Nisan 1994'den itibaren hesaplanmaktadır. Belirtilen endeks başlangıç ayları dikkate alınarak oluşturulan veri seti, Kasım 2012'de son bulmaktadır. Şok tespiti için üç farkı kriterin dikkate alındığı çalışmada her iki endeks için negatif şoklarda aşırı tepkinin geçerli olduğu, pozitif şoklarda ise şok sonrası tepkilerin anlamlı olmadığı tespit edilmiştir. Çalışma sonucunda endekslere yönelik hipotezler çerçevesinde yorum bulunmamaktadır. Bulgular, BBH'yi desteklemektedir.

Polat, Türker ve Köse (2016), BIST Spor Endeksinin pozitif şoklara tepkisini araştırmışlardır. Sadece bir endeksin tepkisinin ele alındığı çalışmada endekse yönelik çalışmaların kısıtı olması, endeks seçiminde belirleyici olmuştur. 1.1.2011-31.3.2015 dönemi getiri verileri ile seçilen endeksin hem kendisinde hem de piyasa genel endeksinde görülen şoklara tepkisi analiz edilmiştir. Endeksin kendi şoklarına tepkisine yönelik bulgular DTH ile uyumludur. Çalışmaya kıyaslama amaçlı dahil edilen yedi ticari bankanın hisse senetlerinin tamamında EPH ile uyumlu sonuçlar raporlanmıştır.

\section{Veri Seti ve Metodoloji}

Endeksler üzerinden piyasa tepkisini ele alan bu çalışmamızda, BiST tarafından uzun süredir hesaplanan temel endekslerin kapanış değerleri kullanılmıştır. Bu endekslerden tüm hisseleri içerir XUTUM ve XU100 endeksleri, en genel ve temel endekslerdir. Endekslerde yer alacak payların seçiminde fiili dolaşımda bulunan kısmın piyasa değeri (kapitilizasyon) ile günlük ortalama işlem hacimleri dikkate alınmaktadır (BIST Endeks ve Veri Direktörlüğü, 2018:9). Bloomberg'den alınan verilere göre seçilen endekslerin 31.08.2018 itibariyle yaklaşık kapitilizasyon değerleri Tablo 1'de sunulmuştur. 
Tablo 1. Seçilen Endekslerinin 31.08.2018 itibariyle Yaklaşık Kapitilizasyon Değerleri (Milyon TL)

\begin{tabular}{|l|l|r|r|}
\hline Endeks & Kısaltma & $\begin{array}{c}\mathbf{3 1 . 0 8 . 2 0 1 8} \text { itibariyle } \\
\text { Piyasa Kapitilizasyonu }\end{array}$ & $\begin{array}{c}\text { BiST Tüm } \\
\text { Endeksine } \\
\text { Oranı (\%) }\end{array}$ \\
\hline BiST 100 Endeksi & XU100 & $632,158.29$ & 79.92 \\
\hline BiST SInai Endeksi & XUSIN & $294,308.64$ & 37.21 \\
\hline BiST Mali Endeks & XUMAL & $316,941.59$ & 40.07 \\
\hline BiST Tüm Endeksi & XUTUM & $790,955.38$ & 100.00 \\
\hline BiST 30 Endeksi & XU030 & $452,472.70$ & 57.21 \\
\hline BiST Holding Endeksi & XHOLD & $103,733.43$ & 13.11 \\
\hline BiST 50 Endeksi & XU050 & $541,984.29$ & 68.52 \\
\hline BiST Tüm-100 Endeksi & XTUMY & $158,797.09$ & 20.08 \\
\hline BiST 100-30 Endeksi & XYUZO & $179,685.59$ & 22.72 \\
\hline BiST Banka Endeksi & XBANK & $178,084.42$ & 22.52 \\
\hline
\end{tabular}

BiST'te işlem gören (menkul kıymet yatırım ortaklıkları hariç) tüm paylardan oluşan BiST Tüm Endeksi'ne kıyasen, çok daha az şirketin dahil olduğu, ancak genel içerisinde fazlaca ağırlığı olan paylardan oluşan, dolayısıyla şirket başına daha yüksek piyasa değerlerine sahip olan endeksler sırasıyla XU030, XU050 ve XU100 endeksleridir. Daha az sayıda paydan oluşan bu endekslerin seçimi likidite hipotezi açısından anlamlıdır. Diğer taraftan XU100 dışında kalan paylardan oluşan XTUMY endeksi, düşük piyasa değerine sahip, daha küçük firmaları temsil etmekte, Endeks Çeşitlendirmesi hipotezi açısından anlam taşımaktadır. Illk 30 dışında kalan, ancak en yüksek değere sahip 70 paydan oluşan XYUZO endeksinin seçimi de ölçek etkisine dayanmaktadır. Payları bu endekste yer alan şirketlerin kapitilizasyonu, borsa genelinin \%22,72'sine karşılık gelmektedir.

Tablo 2. Seçilen BiST Endekslerinde Pay Sayıları (31.08.2018)

\begin{tabular}{|c|c|c|c|c|c|c|c|c|c|c|}
\hline XBANK & 13 & & & & & & & & & \\
\hline XHOLD & 0 & 35 & & & & & & & & \\
\hline XTUMY & 3 & 17 & 229 & & & & & & & \\
\hline XU030 & 6 & 6 & 0 & 30 & & & & & & \\
\hline XU050 & 8 & 11 & 0 & 30 & 50 & & & & & \\
\hline XU100 & 10 & 18 & 0 & 30 & 50 & 100 & & & & \\
\hline XUMAL & 13 & 35 & 58 & 13 & 20 & 35 & 93 & & & \\
\hline XUSIN & 0 & 0 & 118 & 9 & 16 & 41 & 0 & 159 & & \\
\hline XUTUM & 13 & 35 & 229 & 30 & 50 & 100 & 93 & 159 & 329 & \\
\hline XYUZO & 4 & 12 & 0 & 0 & 20 & 70 & 22 & 32 & 70 & 70 \\
\hline
\end{tabular}

Çalışmamızda, ilave olarak belirli sektörlere özgü olan XBANK, XHOLD, XUMAL ve XUSIN endekslerinin seçilmesinde de yukarıda belirtilen hipotezler etkili olmuştur. Piyasalara fon sağlama işlevi gören bankaların önemli bir kısmını temsil eden XBANK endeksine yönelik haberlerin daha geniş bir kitle tarafından izleniyor olması beklentisi, Endeks Çeşitlendirmesi Hipotezinin genel savı bakımından ayrıca anlamlıdır. Hipotezin öne sürdüğg̈ ölçeğin yanında bankaların kitlesel olarak göz önünde olması karşııında, bu endekste bilgi etkinliğinin geçerli olması beklenebilir.

Endeksleri oluşturan pay sayıları ve ortak pay (firma) sayıları Tablo 2'de görülmektedir. Sınai endeksi oluşturan firmaların yaklaşık 3/2'ünün kapitilizasyon bakımından daha düşük değere sahip XTUMY endeksinde 
yer alması da dikkat çekicidir. Seçilen endekslerden XTUMY ve XYUZO; 2009 yılı, geri kalan sekiz endeksten biri olan XU050 endeksi ise 2000 yılı başından itibaren hesaplanmaktadır. Dolayısıyla seçilen endekslerin neredeyse tamamı için 18 yılı aşan veri söz konusu olmaktadır. 18 yıllık dönemin iki ayrı pencerede ele alınması ile nispeten daha küçük firmaları temsil eden iki endeksin analize dahil edilmesi sağlanmıştır.

Literatürde getiriler, genellikle aritmetik formda hesaplanmaktadır. $D$ endeks değerini ve $i$, endeksi ifade etmek üzere Denklem 1'de verilen formül kullanılarak tüm endeksler için getiri serileri oluşturulmuştur.

$$
R_{i, t}=\frac{D_{i, t}-D_{i, t-1}}{D_{i, t-1}}
$$

Tablo 3'de her iki pencere için geçerli olan dönem aralığı ve işlem günlerine dayanarak oluşturulan veri setlerinin uzunluğu sunulmuştur. Finansal zaman serilerinde gözlenen tipik özellikler, BísT endeksleri getiri serileri için de geçerlidir. Tanımlayıcı istatistiklerden serilerin normal dağılım göstermedikleri izlenmektedir. Oluşumu 2000 ve daha öncesine giden sekiz endeks için dönemler bazında dağılımların kuyrukları bazında farklılık dikkat çekmektedir. 2008 yılı sonrasında kuyrukların nispeten daha inceldiği görülmüştür. Bu olgu, maksimum ve minimum değerler arasındaki aralıkların ikinci dönemde azalması ile de teyit edilmektedir. Diğer taraftan 2009 yılında oluşturulduğu için yalnızca ikinci dönem verisi söz konusu olan XTUMY ve XYUZO endekslerinin getiri serilerindeki basıklık değerleri, diğer sekiz serinin ilk dönemki değerleri dikkate alındığında bile genel olarak daha yüksektir. Nispeten küçük firmaları temsil eden endeksler ölçek bazında kırılganlığa işaret etmekte, yüksek minimum getiriler bu bulguyu güçlendirmektedir. Çarpıklık istatistiği, endekse bağlı olmaksızın iki dönemi ayırt eden önemli bir göstergedir. Pozitif uç değerler ile negatif uç değerler karşılaştıııldı̆ıında, ilk dönemde pozitif yönde olan istatistik, pozitif getirilerin sayıca çokluğuna bağlanabilir. İzleyen dönemde çarpıklık değerlerinin negatife dönmesi, ortalama ve medyan değerleri de dikkate alındığında, negatif uç değerlerin etkisinden kaynaklanmaktadır. Uç değerler bağlamında, bu dönemin küresel krizin olası etkilerini barındırdığı göz önünde bulundurulmalıdır.

Endekslerde kazanan/kaybeden portföyünü ya da tarihleri belirleyebilmek için \pm yönde fiyat şoklarının filtrelenmesi gerekmektedir. Lasfer vd. (2003), referans çalışmalara atıfla bazı çalışmalarda haftalık bazda \%50 ve üzeri fiyat değişimi, 300 günlük penceredeki en büyük günlük fiyat değişimi gibi kriterlerin dikkate alındığını belirtmektedir. Volatiliteyi dikkate almayan, tek değişkene bağlı bu yaklaşımların yanlışlığına dikkat çeken araştırmacıların herhangi bir günün beklenen getirisi için belirledikleri kriter, geriye dönük 60 gün ile 11 gün arasında kalan, [-60:-11], 50 günlük penceredeki ortalama getiridir. Schnusenberg ve Madura'nın (2001) kullandıkları benzer pencerede, yukarıda ifade edildiği gibi geriye dönük 10 günlük fasıla bulunmamaktadır. Dolayısıyla 60 günlük bir pencere genişliği kullanılmaktadır. Lasfer vd. (2003), bazı örneklerde birbirini izleyen iki şokun arasında 10 günden daha kısa sürenin söz konusu olduğunu belirterek birbirine karışması muhtemel etkileri gidermek üzere bu seçimi yaptıklarını vurgulamıştır. Gözlem bazında olmak üzere, 50 günlük pencerede hesaplanan ortalama (beklenen) getiriden \pm yönde 2 standart sapmadan uzağa düşen getiriler, \pm fiyat şokları olarak belirlenmektedir.

Çalışmada açık bir şekilde ifade edilmemesine karşın şokların tayin edilmesine yarayan standart sapma ölçüsü de hareketli şekilde 50 günlük pencerede belirlenmektedir. Zira aynı yöntemi uygulayan Spyrou vd. (2007), dört İngiltere hisse senedi endeksini bu çalışmaya benzer şekilde iki pencerede ele almışlardır. Her iki pencere için tablo halinde verilen şok sayılarının endeks ve şok türü bazında toplamı, yine aynı tabloda sunulan genel şok sayıları ile uyumludur. Dönemlerin volatilite bazında farklılaştığı dikkate alındığında bu uyum, hareketli volatilite ile mümkün olabilmektedir. Bu çalışmada da ayrıca raporlanmamakla birlikte sekiz endeks için yapılan toplu analizde saptanan şok sayılarının dönemler ile uyumlu olduğu saptanmıştır. 
BiST Endekslerinin Şoklara Kısa-Dönemli Tepkisi: Bir Makro Analiz

Tablo 3. Seçilen BIST Endeksleri Getiri Serilerinin Tanımlayııı İstatistikleri

\begin{tabular}{|c|c|c|c|c|c|c|c|c|c|c|}
\hline \multicolumn{11}{|c|}{ A. 01.01.2000 - 31.12.2008 } \\
\hline & XBANK & XHOLD & XU030 & XU050 & XU100 & XUMAL & XUSIN & XUTUM & & \\
\hline Gözlem Sayısı & \multicolumn{8}{|c|}{2247} & & \\
\hline Ortalama (\%) & 0.078 & 0.037 & 0.058 & 0.055 & 0.054 & 0.062 & 0.052 & 0.054 & & \\
\hline Medyan (\%) & 0.033 & -0.067 & -0.004 & 0.026 & 0.048 & 0.049 & 0.081 & 0.050 & & \\
\hline Minimum (\%) & -19.079 & -18.263 & -18.182 & -18.142 & -18.109 & -18.814 & -16.485 & -17.872 & & \\
\hline Maksimum (\%) & 18.843 & 19.659 & 19.299 & 19.374 & 19.451 & 19.071 & 19.775 & 19.335 & & \\
\hline Std. Sapma (\%) & 3.098 & 2.884 & 2.757 & 2.686 & 2.640 & 2.919 & 2.311 & 2.550 & & \\
\hline Çarpıklık & 0.339 & 0.334 & 0.365 & 0.331 & 0.314 & 0.317 & 0.255 & 0.282 & & \\
\hline Basıklık & 7.234 & 7.709 & 8.125 & 8.431 & 8.757 & 7.594 & 11.243 & 9.177 & & \\
\hline JB İst. & $1,721.7$ & $2,117.8$ & $2,509.5$ & $2,802.3$ & $3,139.6$ & $2,013.5$ & $6,385.1$ & $3,601.5$ & & \\
\hline $\operatorname{Pr}(J B)$ & 0.001 & 0.001 & 0.001 & 0.001 & 0.001 & 0.001 & 0.001 & 0.001 & & \\
\hline \multicolumn{11}{|c|}{ B. 01.01.2009 - 31.08.2018 } \\
\hline & XBANK & XHOLD & XU030 & XU050 & XU100 & XUMAL & XUSIN & XUTUM & XTUMY & XYUZO \\
\hline Gözlem Sayısı & \multicolumn{10}{|c|}{2431} \\
\hline Ortalama (\%) & 0.043 & 0.074 & 0.061 & 0.061 & 0.062 & 0.053 & 0.083 & 0.062 & 0.070 & 0.067 \\
\hline Medyan (\%) & 0.034 & 0.102 & 0.079 & 0.097 & 0.100 & 0.056 & 0.142 & 0.111 & 0.149 & 0.150 \\
\hline Minimum (\%) & -11.185 & -10.189 & -10.329 & -10.446 & -10.474 & -10.680 & -10.775 & -10.461 & -10.299 & -11.124 \\
\hline Maksimum (\%) & 9.942 & 7.289 & 7.213 & 7.175 & 7.138 & 8.021 & 6.668 & 7.123 & 6.960 & 6.827 \\
\hline Std. Sapma (\%) & 2.010 & 1.504 & 1.558 & 1.501 & 1.464 & 1.737 & 1.232 & 1.413 & 1.078 & 1.233 \\
\hline Çarpıklık & -0.115 & -0.253 & -0.196 & -0.254 & -0.313 & -0.155 & -0.799 & -0.388 & -1.437 & -1.008 \\
\hline Basıklık & 5.021 & 5.476 & 5.388 & 5.669 & 5.952 & 5.246 & 9.293 & 6.324 & 15.240 & 10.348 \\
\hline JB İst. & 419.2 & 647.2 & 593.1 & 747.6 & 922.3 & 520.5 & $4,270.2$ & $1,179.9$ & 16,011 & $5,880.2$ \\
\hline $\operatorname{Pr}(J \mathrm{~B})$ & 0.001 & 0.001 & 0.001 & 0.001 & 0.001 & 0.001 & 0.001 & 0.001 & 0.001 & 0.001 \\
\hline
\end{tabular}

Şokların filtrelenmesinde düşünülebilecek diğer bir alternatif, Üstel Ağılıklandırılmış Hareketli Ortalama (EWMA) yönteminin kullanılmasıdır. EWMA, yakın zamanlı olanları daha fazla olmak üzere gözlemleri, üstel azalan biçimde ağırlıklandırmaktadır. Sözü edilen diğer çalışmalarda ise, 50 günlük pencerede eşit ağırlıklandırma geçerlidir. Yakın zamanlı veriye daha fazla ağırlık verilmesi hem finansal serilerde gözlenen kümelenme hem de haberlerin çabuk eskimesi olgularına daha uyumludur, dolayısıyla daha gerçekçidir. Brooks' un (2008) verdiği EWMA denklemi, yukarıda belirtilen aynı 50 günlük pencere geçerli tutulmak kaydıyla, değiştirilerek kullanılmıştır. EWMA yöntemine dayalı volatilite serileri, Denklem 2 kullanılarak oluşturulmuştur.

$$
\sigma_{i, t}=\sqrt{(1-\lambda) \sum_{j=11}^{60} \lambda^{(j-11)}\left(R_{i, t}-\bar{R}_{l}\right)^{2}}
$$

Lambda $(\lambda)$ parametresi için RiskMetrics tarafından önerilen 0,94 değeri dikkate alınmıştır. Bu değer, J.P. Morgan/Reuters'in (1996) RiskMetrics ${ }^{\circ}$ teknik dokümanında farklı Lambda ve pencere genişlikleri için verdikleri tablonun arka planındaki hesaplama dikkate alınırsa 50 gözlem ile $\% 4,53$ tolerans seviyesine tekabül etmektedir. EWMA volatilitesinin öngörü odaklı güncellemesinde bir önceki volatilite ve getiri değerleri dikkate alınmaktadır. Filtreleme maksadıyla yapılan buradaki kullanımda tüm getiri değerlerine Denklem 2, aynı şekilde uygulanmıştır. 
Lasfer vd. (2003) ile Spyrou vd.'nin (2007) kullandığı hareketli standart sapma ile EWMA volatilitesi arasında şok sayısı bakımından tespit edilen fark, en fazla XUMAL endeksinde gözlenmiştir. Bu endeks için, her iki çalışmada dikkate alınan şok eşiği değeri 2 yerine, 2,5758 eşik değeri ile yapılan filtreleme (2. dönem için) Şekil 1'den izlenebilmektedir. Eşik değerinin seçimi ve analize etkileri ilerleyen bölümde ele alınacaktır.

Şekil 1. XUMAL Endeks Getirisi Hareketli Std. Sapma ve EWMA Volatilite Filtreleri (2009-2018)

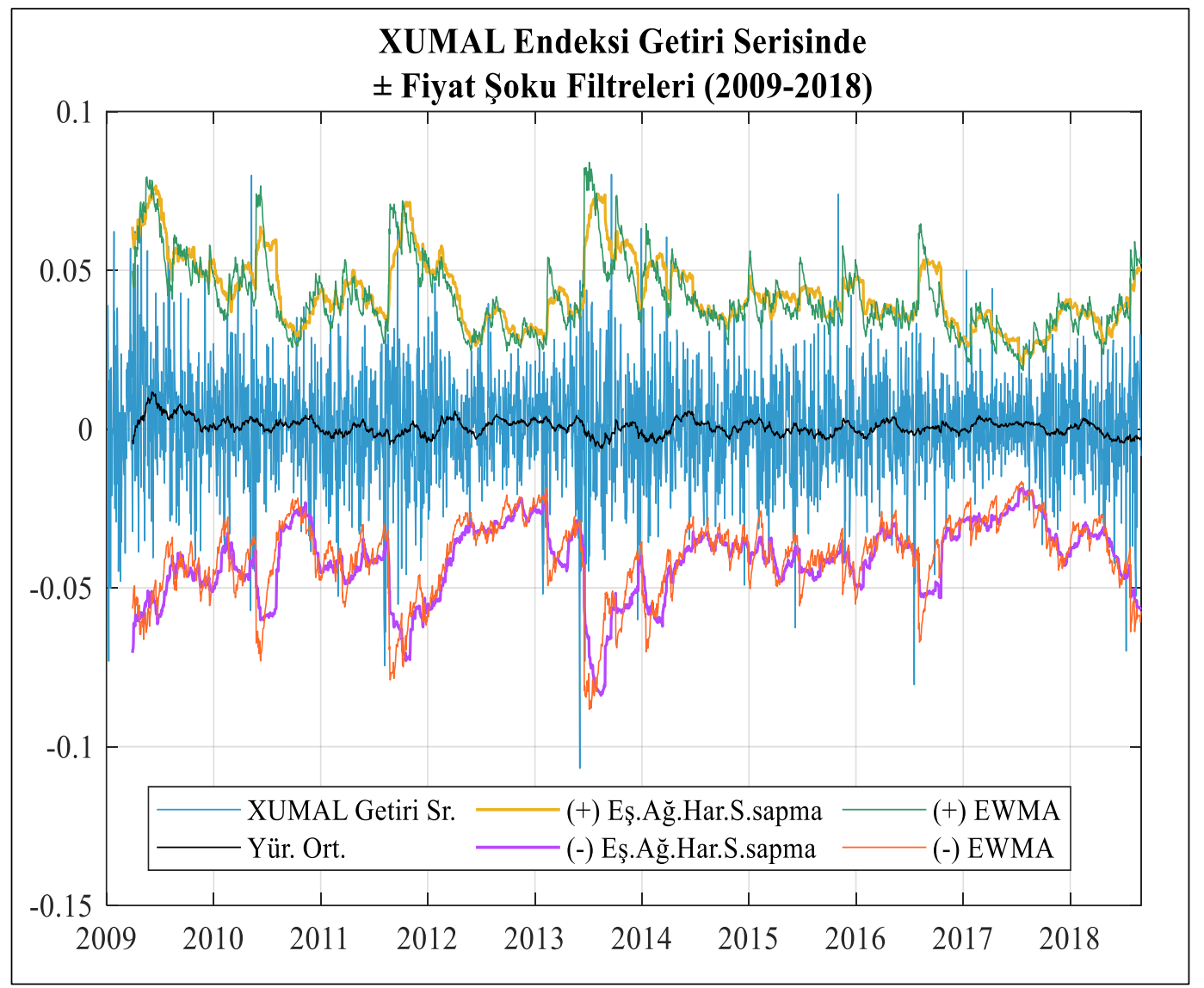

Volatilite tahmininde dikkate alınan EWMA ile eşit ağırlıklandırma yöntemlerinin ayrı ayrı uygulanması neticesinde EWMA yönteminin, bazı serilerde geçerli olmamak kaydıyla, genel olarak daha fazla şoku yakaladığı tespit edilmiştir. İki yöntemin uygulamasında gözlenen farklılı̆ıı Şekil 2, görsel olarak ortaya koymaktadır. Grafiklerden de izleneceği üzere EWMA volatilitesi, piyasadaki dalgalanma ya da sakinleşme karşısında daha hızlı tepki verebilmektedir. Eşit ağırlıklı yöntemde ise 50 günlük penceredeki tüm değerler tahmine eşit oranda dâhil olmakta, dolayısıyla yöntemin sakinleşme temayülündeki piyasa volatilitesine adaptasyonu geç olmaktadır.

Eşit ağırlıklı yönteme göre tespit edilen 29.04.2009 tarihli pozitif şokta Nisan ayının ilk iki haftasında gözlenen fiyat yükselişlerinin etkili olduğu, şekildeki sağ üst grafikten izlenebilmektedir. EWMA yöntemi ile belirlenen sınırın getiri değerine çok yakın olduğu da görülmektedir. Gözlenen bu farklılığın sınır bölgede ortaya çıkması dikkat çekici olmakla beraber, EWMA'nın genel olarak ani fiyat değişimleri sonrasında gerçekleşen hareketleri daha hızlı kapsadığı belirtilebilir. Farklılaşan diğer şoklarda da benzer durum geçerli olmaktadır. 
Şekil 2. Şok Tespitinde Eşit Ağırıklı Hareketli Standart Sapma ve EWMA Kıyaslaması

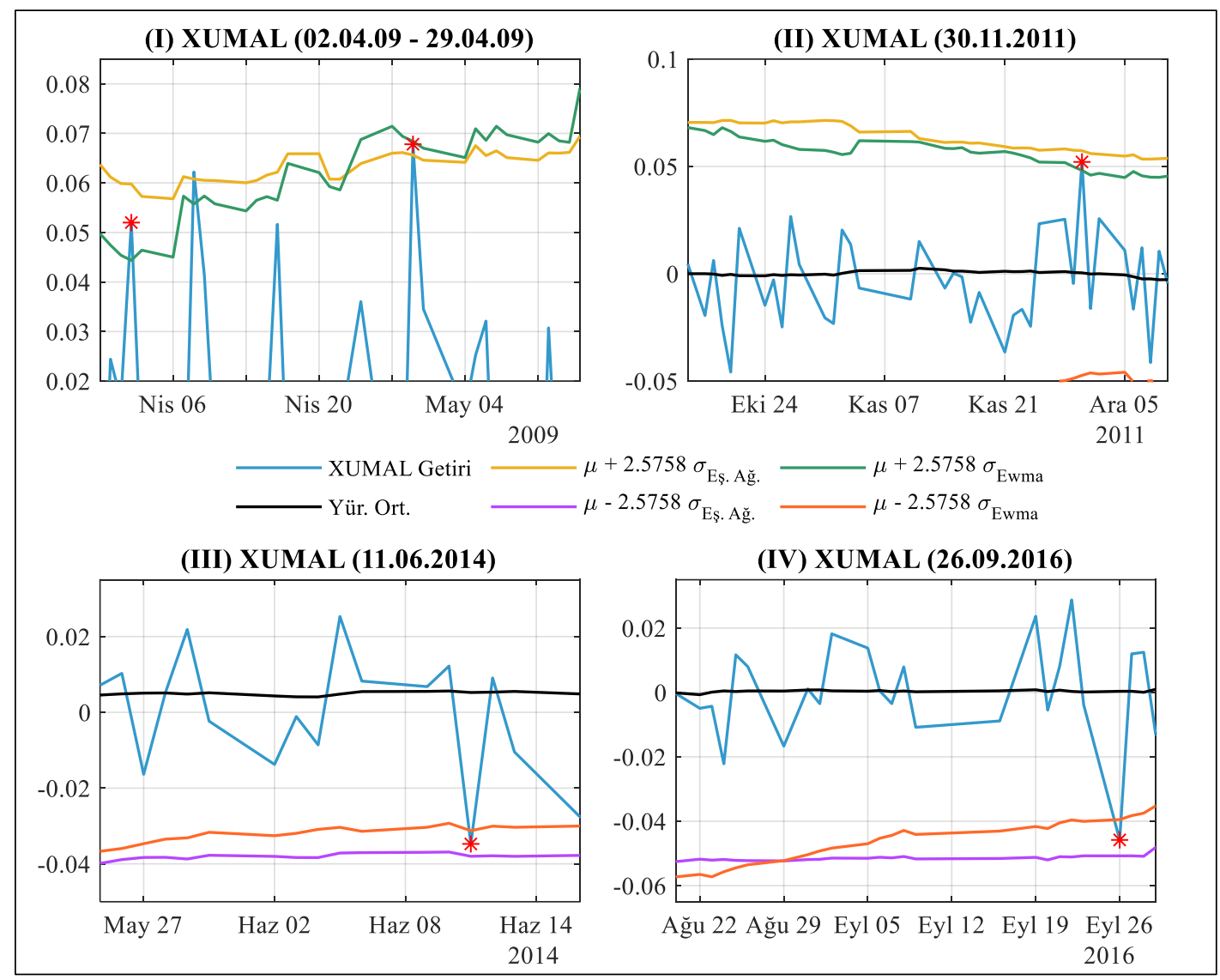

Filtreleme işlemi, 50 günlük pencereye ve gözlem tarihi itibariyle 11 gün öncesine kadar olan filtrasyona dayanmaktadır. Verinin içerdiği tüm bilgi setini kullanarak filtrelemede Hull (2014) tarafından EWMA Modeli'ni de kapsadığı belirtilen ve daha popüler olan GARCH sınıfı modellerin uygulanması mümkündür. Bu yaklaşım, geçmişe dönük verilerle hareketli olarak hesaplanan istatistiklerin dönem bağımsız uyumu ile çelişeceğinden dikkate alınmamıştır.

Lasfer vd. (2003) tarafından kullanılan hareketli ortalama ve standart sapmaya dayalı şok eşiği, yukarıda belirtildiği gibi 2'dir. Günlük ve daha yüksek frekanslı finansal serilerle yapılan yakın zamanlı çalışmalarda fiyat sıçramaları için daha yüksek eşik önerilmektedir. Örneğin, Lee ve Mykland'ın (2008) geliştirdiği teste göre eşik, günlük frekansta seri için \%90 güven aralığında 5,13 olarak hesaplanmaktadır. Şokların daha uç değerde olanlarının fiyat sıçramaları olarak nitelendirildiği düşünülebilir, ancak şokların ayrıştırılmasında seçilen kriterler de araştırmacıların tercihine dayanmaktadır. Normal dağılım altında gözlemlerin \%1'ini, serinin kalanından ayıran eşik değeri 2,5758'dir. Referans çalışmanın dayandığı 2 eşiği ise şokların, gözlemlerin yaklaşık \%4,50'sine tekabül ettiğini varsaymaktadır.

Yüksek frekanslı serilerde kullanılan yüksek eşikler, hisse senetlerinden oluşan portföy ya da endeksler için çeşitlendirme etkisi nedeniyle anlamlı değildir. Yüksek eşik seçilmesi durumunda ulaşılacak şokların sayıca az olması, izleyen analizlerin istatistiki analizinde de engel teşkil edecektir. Öte yandan şokun şiddetine bağlı olarak analiz edilecek tepkinin daha anlamlı olacağı tarafımızca değerlendirilmiştir. Gözlemlerin \%1'ine tekabül eden şok sayısı, bu açıdan uygun bulunarak 2,5758 eşiği esas alınmıştır.

Belirlenen eşik ve EWMA yöntemine dayanarak uygulanan filtreleme ile tespit edilen bir şokun gerçekleştiği gün ve bunu izleyen günler için Anormal Getiri (AR), şok için geçerli 50 günlük penceredeki ortalama getiri, $E\left(R_{i, t}\right)$ dikkate alınarak Denklem 3 yardımıyla hesaplanmıştır. Hesaplama, tüm şoklar için yapılmıştır. 
$A R_{i, t}=R_{i, t}-E\left(R_{i, t}\right)$

Piyasanın tepkisini ölçmek üzere Spyrou vd.'ni (2007) takiben şoku izleyen 20 gün için Birikimli Anormal Getiriler (CARs) Denklem 4 ile bulunmuştur. Birikimli anormal getirilerin istatistiksel olarak anlamlılı̆ıının sınanmasında endeks ve şok türü bazında ortalamaları ve standart sapmalarından yararlanılmıştır.

$$
C A R_{i, t}=\sum_{t=1}^{20} A R_{i, t}
$$

\section{Ampirik Bulgular}

Filtreleme sonucu tespit edilen şoklara ilişkin istatistikler dönem ve şok türü bazında Ek 1.'de yer alan Tablo 4'den izlenebilmektedir. Her iki döneme ait verisi bulunan sekiz endekste, XUMAL ve XUTUM'da daha az belirgin olmak üzere, ikinci dönemde negatif şok sayılarının arttığı gözlenmektedir. Yine bu dönemde negatif şokların oluşma sıklığı, pozitif olanlara kıyasla önemli ölçüde yüksektir. Bu bağlamda diğer önemli bir bulgu ise, endekslerin geneli itibariyle ikinci dönemde pozitif şok sıklığının azalışı, negatif şok sıklığının artışı neticesinde şok türü bazında gözlenen asimetrinin ön plana çıkmasıdır.

Tablo 5. Şoklara Tepkilerin Endeksler Arasında Karşılıklı Olarak Değişkenliğine Yönelik Test Sonuçları (20092018)

\begin{tabular}{|c|c|c|c|c|c|c|c|c|c|}
\hline \multicolumn{10}{|c|}{ (a) Pozitif Şoklar } \\
\hline XHOLD & $* * * 5.10$ & & & & & & & & \\
\hline XTUMY & $* * * 7.48$ & $* * * 3.21$ & & & & & & & \\
\hline XU030 & $* * * 4.02$ & -1.20 & $* * *-4.25$ & & & & & & \\
\hline XU050 & $* * * 4.39$ & -0.79 & $* * *-3.89$ & 0.41 & & & & & \\
\hline$x \cup 100$ & $* * * 4.93$ & -0.21 & $* * *-3.41$ & 1.00 & 0.58 & & & & \\
\hline XUMAL & $* * 2.17$ & $* * *-2.72$ & $* * *-5.35$ & -1.65 & $* *-2.02$ & $* *-2.55$ & & & \\
\hline XUSIN & $* * * 6.34$ & * 1.71 & -1.50 & $* * * 2.82$ & $* * 2.44$ & * 1.92 & $* * * 4.10$ & & \\
\hline XUTUM & $* * * 5.38$ & 0.34 & $* * *-2.91$ & 1.53 & 1.12 & 0.55 & $* * * 3.01$ & -1.40 & \\
\hline \multirow[t]{2}{*}{$X Y \cup Z O$} & $* * * 6.85$ & $* * 2.21$ & -1.12 & $* * * 3.33$ & $* * * 2.94$ & $* * 2.42$ & $* * * 4.57$ & 0.43 & * 1.88 \\
\hline & XBANK & $X H O L D$ & XTUMY & xU030 & XU050 & XU100 & XUMAL & XUSIN & XUTUM \\
\hline \multicolumn{10}{|c|}{ (b) Negatif Şoklar } \\
\hline$X H O L D$ & $* * *-4.24$ & & & & & & & & \\
\hline XTUMY & $* * *-6.46$ & $* * *-3.04$ & & & & & & & \\
\hline xU030 & $* * *-3.51$ & 0.69 & $* * * 3.48$ & & & & & & \\
\hline XU050 & $* * *-3.93$ & 0.17 & $* * * 2.99$ & -0.49 & & & & & \\
\hline xU100 & $* * *-4.01$ & 0.04 & $* * * 2.85$ & -0.60 & -0.12 & & & & \\
\hline XUMAL & $* *-2.23$ & $* * 2.05$ & $* * * 4.62$ & 1.32 & * 1.79 & * 1.89 & & & \\
\hline XUSIN & $* * *-5.50$ & $*-1.74$ & 1.30 & $* *-2.28$ & $*-1.78$ & -1.65 & $* * *-3.51$ & & \\
\hline XUTUM & $* * *-4.08$ & -0.08 & $* * * 2.70$ & -0.71 & -0.23 & -0.12 & $*-1.98$ & 1.51 & \\
\hline \multirow[t]{2}{*}{$X Y \cup Z O$} & $* * *-5.71$ & $* *-2.05$ & 0.95 & $* *-2.57$ & $* *-2.07$ & $*-1.94$ & $* * *-3.76$ & -0.33 & $*-1.80$ \\
\hline & XBANK & XHOLD & XTUMY & xU030 & $x \cup 050$ & XU100 & XUMAL & XUSIN & XUTUM \\
\hline
\end{tabular}

Seçilen tüm endekslerde saptanan şoklara karşı tepkiler, istatistiksel olarak anlamlıdır. Tabloda verilen ortalama tepkiler, anormal getirilerin ortalaması alınarak bulunmuştur. íkinci dönemde \pm şoklara karşı tepkilerin büyüklüğü, önemli ölçüde azalmıştır. Tepkilerin maksimum ve minimum değerleri için de aynı 
farklılaşma geçerlidir. Bu farklılaşma, dönemlerin piyasa volatilitesi bakımından Tablo 3'te de gözlenen ayrışmasını teyit eder niteliktedir.

Spyrou vd. (2007), şoklara tepkinin, portföyler (endeksler) arasında değişkenlik gösterip göstermediğini de test etmişlerdir. Anılan çalışmada varyansların eşit olmaması ${ }^{2}$ varsayımına bağlı olarak istatistiği verilen t testi, endeks şokları ikili gruplar halinde alınarak uygulanmıştır. Birinci dönemde sınai endekste (XUSIN) gözlenen negatif şoklar, XU050 ve XU100 dışında kalan endekslerdeki negatif şoklardan anlamlı olarak ayrışmaktadır. Diğer tüm endeks ikilileri için şok günü gerçekleşen tepkilerde anlamlı farklılaşma bulunamamıştır. İkinci dönemde sayı ve anlamlılık yönüyle daha fazla olmak üzere saptanan ortalama tepki farklılı̆ı, Tablo 5'te sunulmuştur.

Şoklara verilen tepkilerde endeksler arasındaki ayrışma, ikinci dönemde daha belirgin hale gelmektedir. BIST Banka endeksinde (XBANK) her iki şok türü için ortalama tepkiler, diğer endekslerde gözlenenlerden anlamlı olarak farklıdır. XBANK için geçerli olan iyi ve kötü haberlere daha kuvvetli tepkisellik, bankacılık sektörünün yukarıda belirtilen hassasiyeti kapsamında değerlendirilebilir. Diğer yandan toplam piyasa değerindeki payı nispeten düşük olan (\%20, \%23 ve \%37) XTUMY, XYUZO ve XUSIN endekslerinde gözlenen tepkiler $t$ testine göre her iki yönde geçerli olmak üzere birbirine yakındır. Şoklara daha az tepkinin gözlendiği bu üç endeksin diğer endekslerden anlamlı olarak farklılığı, düşük değere sahip hisse senetlerinin yatırımcılar tarafından daha az takip edilmesine bağlanabilir, ancak şok sonrası tepkileri yansıtan birikimli anormal getiriler de dikkate alınmalıdır.

Diğer taraftan, piyasanın değer bakımından sırasıyla yaklaşık \%80, \%68 ve \%57'sini ifade eden BísT 100, 50 ve 30 endekslerindeki yakınlaşma da dikkat çekicidir. Göreceli olarak daha küçük şirketleri temsil eden üç endekste gözlenen tepkiselliğin zıddına yüksek değere sahip bu endekslerde mutlak değer cinsinden \pm yönde tepkiler daha güçlüdür. Değer boyutunda tespit edilen bulgu, Endeks Çeşitlendirmesi Hipotezi kapsamında, izleyen dönemdeki hareketlerle birlikte değerlendirilmelidir.

Tepkileri açıklayıcı hipotezlerin değerlendirilebilmesi açısından şok sonrası birikimli anormal getirilerin analiz edilmesi gerekmektedir. Denklem 4 kullanılarak bulunan birikimli anormal getirilerin şok türü bazında ortalamaları, Ek 2 de yer alan Tablo 6'dan izlenmektedir. Tabloda şoku izleyen işlem gününden başlamak üzere 20. işlem gününe kadar gerçekleşen değerler listelenmiştir. Geneli itibariyle negatif şoklar sonrası istatistiksel olarak anlamlı birikimli tepkiler gözlenmemektedir.

Her iki dönemde şoklara karşı tepkiler aynı zamanda görsel olarak Şekil ve Şekil 'de ele alınmıştır. Birinci dönemde tüm endeksler için pozitif şoklar sonrası artarak devam eden pozitif yönde kümülatif anormal getiri değerleri, DTH ile uyumludur. Ek 2. Tablo 6'dan BiST Sınai endeksi dışında birikimli anormal getirilerin şoku izleyen 15. ve bunu izleyen birkaç günde anlamlı olduğu görülmektedir. Endekslerde sistematik olarak gözlenen pozitif ve belli bir dönemden sonra artış trendiyle anlam kazanan tepki, düşük tepkinin gecikmeli olarak gerçekleştiğini göstermektedir. Negatif şoklar için ise istikrarlı bir tepkiden söz etmek mümkün değildir. Sağ alt grafikte XUTUM, XU100 ve XU050 endekslerinde 2. ve 6. günler arasında sınırlı da olsa aşırı tepki izine rastlanmaktadır. Ancak, tüm endeksler için geçerli olmak üzere negatif şoklarda herhangi bir hipotezi güçlü şekilde destekleyen kanıta ulaşılmamaktadır.

2009 ve sonrası döneme ilişkin olarak negatif şoklar sonrası tepkileri ele alan Şekil 4'ün alt satırında bulunan grafiklerde kümülatif anormal getirilerin negatif bölgede yoğunlaşmış olması, ATH'ye aykırılık teşkil etmektedir. Üst satırdaki grafiklerde ise, XUSIN endeksi hariç tutulursa, inişli ve çıkışlı seyrettiği görülen ortalama birikimli getiriler, aşırı ve düşük tepki hipotezlerini destekler mahiyette değildir. Grafikler birlikte değerlendirildiğinde iki husus dikkat çekmektedir. BiST Sınai endeksinde pozitif şoklar sonrası 3-12. günlerde izlenen negatif birikimli getiriler ATH ile uyumludur. Ek 2. Tablo 6'dan şok sonrası 7. günde bu tepkinin istatistiksel olarak anlamlı hale geldiği de görülmektedir. Özet halinde sunulan tabloda verilmeyen günlere bakıldığında 7. gün haricinde anlamlı ilişki tespit edilememiş olması, ATH'nin geçerliliğinin sınırlı olduğunu göstermektedir. Grafiklerde dikkat çeken ikinci nokta, XUTUM, XU100 ve XU050 endekslerinde 3. güne kadar her 2 şok türünde geçerli olan minimal ölçekteki aşırı tepkidir. Ancak bulgu, hipotezi sistematik ve anlamlı bir şekilde desteklememektedir. 
Şekil 3. Birikimli Getiriler (2000-2008) - (a) Pozitif Şoklar Sonrası, (b) Negatif Şoklar Sonrası

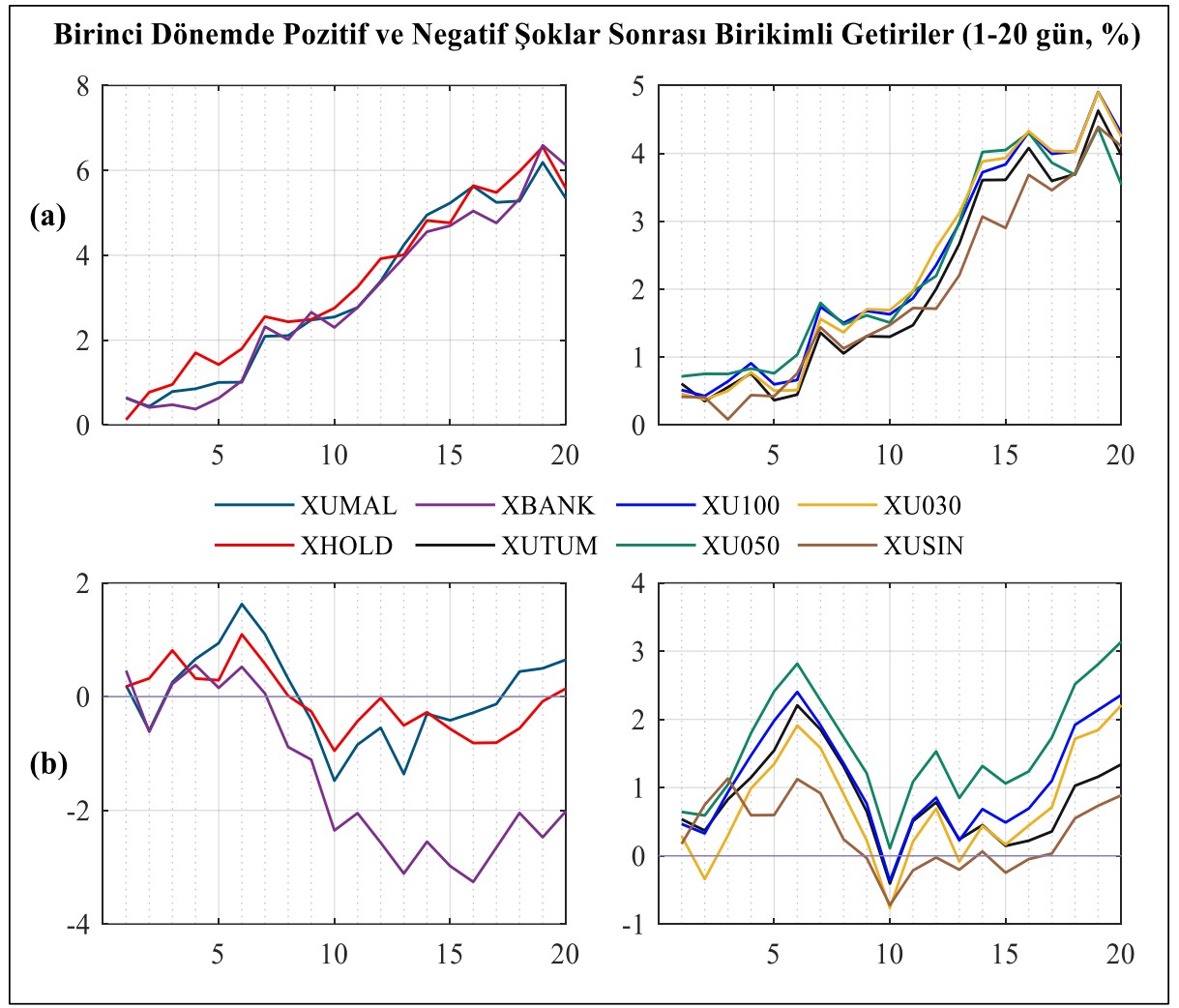

Şekil 4. Birikimli Getiriler (2008-2018) - (a) Pozitif Şoklar Sonrası, (b) Negatif Şoklar Sonrası

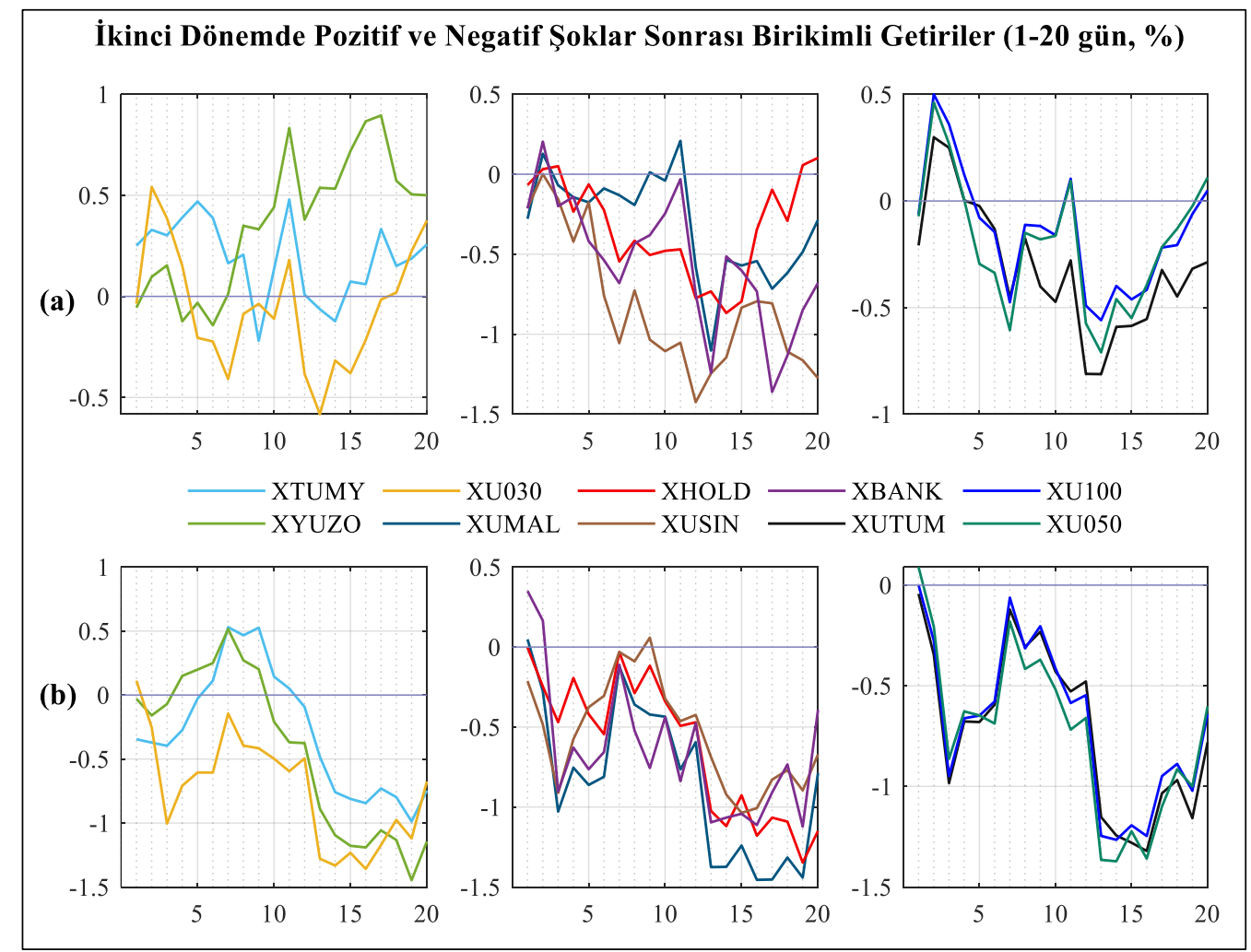




\section{Sonuç ve Öneriler}

Çalışmanın bulgularını, piyasaya dönük gelişmeler ve haberlerin neden olduğu şokların aynı gün fiyat hareketlerine etkileri ve sonrasında yatırımcıların bu etkilerin yeterliliği konusunda verdiği sinyaller ve bu sinyallerin arka planındaki davranışsal faktörler bağlamında ayrı ayrı değerlendirmek mümkündür. Sonuçlar, endeks temelli bir yaklaşım izlendiğinden piyasa geneline ve endeksin içerdiği spesifik özelliklere dönük yorumlanabilir.

İki dönem halinde yapılan analize göre endeks getirilerinin 2000-2008 yılları arasında daha oynak olduğu, buna paralel olarak tespit edilen şokların daha büyük olduğu görülmektedir. Filtrelemede kullanılan EWMA yöntemi bu bağlamda ikinci dönem için daha anlamlı hale gelmiştir. Bu yöntem, daha dar aralıkta gözlenen fiyat hareketlerinde ani yükseliş ve azalışlara karşı yakın zamanlı verilere ağırlık vererek volatilitede daha hızı düzeltme sağlamaktadır. BIST Banka endeksi bu dönemde şoka karşı ilk tepkinin büyüklüğü bakımından diğer endekslerden ayrışmaktadır. Bankacılık sektörünün piyasaları doğrudan etkileme özelliği, geniş kitle tarafından takip ediliyor olması ve düzenlemeye tabi olması \pm yönde görülen yüksek tepkiyi izah eder niteliktedir. Buna karşın küçük firmaların ağırlığının daha fazla olduğu endekslerde ilk tepkiler diğer genel endekslere göre anlamlı şekilde düşük bulunmuştur. Yatırımcıların ilk tepkilerinin kısıtı bilgi nedeniyle sınırlı olması ya da işlem hacimlerinin nispeten düşük gerçekleşmesi bu gelişmede etkili olabilir. illk tepki bakımından birinci dönemde saptanan endeksler arası ayrışmaların ikinci dönem olan 2009-2018 için de geçerli olduğu saptanmıştır. Birikimli anormal getirilere bakıldığında ise, küçük firmaların ağırlığının daha fazla olduğu endekslerde Endeks Çeşitlendirmesi Hipotezi kapsamında beklenmesi olası ATH'ye dair anlamlı bir kanıt elde edilememiştir.

Şoklar sonrası tepkilerde ise endekslerin çoğunda, EPH haricindeki hipotezleri geçerli kılabilecek aşırı ya da düşük tepkiye dair anlamlı bulgular sağlanamamıştır. Özellikle ikinci dönem itibariyle kümülatif anormal getirilerde gözlenen dalgalı örüntü, rassal yürüyüşe daha yakındır. Tepkileri anlamlandırmaya yönelik olarak ele alınan teorik çerçevede öne sürülen hipotezler, daha çok aşırı tepkiyi açıklamaya odaklıdır. Bu bağlamda BIST Sınai endeksinde 2009-2018 dönemi için BBH önermesinin tam tersi bir durum söz konusudur. İyi haberleri temsil eden pozitif şoklar karşısında gösterilen aşırı tepki, ortalama şok büyüklüklerinin bu endeks için düşük düzeyde olduğu dikkate alınırsa yatırımcıların üretim sektörünü temsil eden endekse yönelik kısmen gereğinden daha iyimser bakış açısını yansıtmaktadır. Şok anındaki bu yaklaşımın yaklaşık on gün içerisinde düzeltildiği de görülmektedir.

Endekslerin genelinde ve 2000 - 2008 döneminde geçerli olmak üzere pozitif şokları takiben gözlenen ve anlamlı bulunan düşük tepki, yatırımcıların iyi haberlere temkinli yaklaştığını göstermektedir. Bunun gerisinde pozitif şoklar sonrasında piyasanın kötüye gidebileceğine yönelik kaygılar, diğer ifadeyle ekonomideki kırılganlıklar olabilir. İkinci dönemde aynı durumun geçerli olmaması, piyasanın bilgisel etkinlik anlamında daha olgunlaştığı şeklinde yorumlanabilir.

Çalışmamız kapsamında analiz edilen BisT endekslerinde gözlenen piyasa tepkileri, birinci dönemde pozitif şoklarda görülen düşük tepki dışında, EPH ile uyumludur. Belirli kurallara göre oluşturulan, üyeleri genel olarak sabit kalan portföyler olan endeksler, piyasanın geneline ya da belli bir grubuna yönelik fikir vermektedir. Diğer çalışmalarda piyasamız için geçerliliği tespit edilen ATH'ye yönelik kanıt elde edilememiş olması, bu çerçevede değerlendirilmelidir. Bu açıdan, aşırı tepkinin mikro ölçekte geçerli olduğu söylenebilir. Endekslere yönelik literatürde yer verilen çalışmalar ile kıyaslandığında Schnusenberg ve Madura (2001), Lasfer vd. (2003) ile Spyrou vd.'ne (2007) benzer şekilde düşük tepkiye yönelik bulgulara ulaşılmıştır. Ancak, DTH'yi kısmen destekleyen bulgu, birinci dönem ve sadece pozitif şoklar için geçerlidir. Düşük tepki bulgusu, anılan çalışmaların aksine hemen değil, yedinci günden itibaren anlamlı hale gelmektedir. Ayrıca Spyrou vd. (2007), düşük tepkinin orta ve düşük piyasa değerine sahip hisselerden oluşan endeksler için geçerli olduğu sonucuna ulaşmışlardır. Birinci dönem pozitif şokları için elde ettiğimiz bulgu ise, piyasa değeri bakımından benzer bir ayrışmayı destekler mahiyette değildir. Çalışma bulgularının geneli, Spyrou vd.'nin (2007) yüksek piyasa değeri taşıyan endeksler için saptadığı EPH'nin ele alınan tüm endeksler için geçerli olduğunu göstermektedir. 
Şokların neden olduğu haberleri sınıflandırarak çalışmanın detaylandıııması ve ilerletilmesi mümkündür. Haber türlerine göre yapılacak analize sektör verilerinin dahil edilmesi, sektörlere özgü şokları ve piyasa tepkilerini ayrıntılı incelemeye imkân tanıyacaktır. Ayrıca, ele alınan hipotezlerin geçerliliğinin firma büyüklüğü bazında değişkenliğini araştırmak amacıyla farklı portföy/endekslerin dikkate alınması uygun olacaktır. Bazı büyük firma hisse senetlerinin çalışmaya konu endekslerin geneli üzerinde baskınlığının ve işlem hacimlerinin irdelenmesi, gelecek çalışmalar için yol gösterici olacaktır.

\section{Son Notlar}

1. Çalışmada sözü edilen tepki, endeksler için yapılan kısa dönemli çalışmalara kıyasla daha uzun sürelidir. Bir önceki yıl boyunca yüksek getiri sağlayan hisselerin takip eden 3 aydan 6 aya kadar olan dönemde yüksek getiri sağlamaya devam etmesi Jegadeesh ve Titman'a atfen momentum etkisi olarak nitelendirilmiştir (Fama, 1998:286). Momentum, kısa dönemli ve negatif yönde hareketler için de benzer etkiyi kapsayacak şekilde kullanılmaktadır.

2. Yakın varyansa sahip şok tepkileri gözetilerek uygulanan eşit varyansa dayalı test, sonuçlarda herhangi bir değişikliğe neden olmamaktadır.

\section{Kaynaklar}

Aguiar, R. A., \& Sales, R. M. (2010). Overreact analysis in the American stock market: A fuzzy c-means algorithm approach. International Journal of Trade, Economics and Finance, 1(4), 325-330.

Ali, N., Talib, N. A., Nassir, A. M., \& Abidin S. Z. (2013). Overreaction of syariah stocks: Does size matter? International Journal of Economics ve Management, 7(1), 123-135.

Alonso, A., \& Rubio, G. (1990). Overreaction in the Spanish equity market. Journal of Banking and Finance, 14(2-3), 469481.

Antoniou, A., Galariotis, E. C., \& Spyrou, S. I. (2005). Contrarian profits and the overreaction hypothesis: The case of the Athens Stock Exchange. European Financial Management, 11(1), 71-98.

Barak, O. (2008). iMKB'de aşırı reaksiyon anomalisi ve davranışsal finans modelleri kapsamında değerlendirilmesi. Gazi Üniversitesi iktisadi ve idari Bilimler Fakültesi Dergisi, 10(1), 1-24.

Baytas, A., \& Cakici, N. (1999). Do markets overreact: International evidence. Journal of Banking and Finance, 23(7), 1121-1144.

Blackburn, D. W., \& Cakici, N. (2017). Overreaction and the cross-section of returns: International evidence. Journal of Empirical Finance, 42, 1-14.

Borsa İstanbul A.Ş. Endeks ve Veri Direktörlüğü (2018). BiST pay endeksleri temel kuralları. http://www.borsaistanbul.com/docs/default-source/endeksler/bist-pay-endeksleri-temel-kurallari-haziran2018.pdf?sfvrsn=4 (Erişim Tarihi, 3 Ekim 2018).

Boubaker, S., Farag, H., \& Nguyen, D. K. (2015). Short-term overreaction to specific events: Evidence from an emerging market. Research in International Business and Finance, 35, 153-165.

Bowman, R. G., \& Iverson, D. (1998). Short-run overreaction in the New Zealand stock market. Pacific-Basin Finance Journal, 6(5), 475-491.

Brooks, C. (2008). Introductory econometrics for finance. Cambridge: Cambridge University Press.

Caporale, G. M., Gil-Alana, L., ve Plastun, A. (2015). Long-term price overreactions: Are markets inefficient? DIW Berlin Discussion $\quad$ Paper $\quad$ No. 1444. https://papers.ssrn.com/sol3/Delivery.cfm/SSRN_ID2553187_code428549.pdf?abstractid=2553187\& mirid=1 (Erişim Tarihi, 17 Temmuz 2018).

Caporale, G. M., Gil-Alana, L., \& Plastun, A. (2018). Short-term price overreactions: Identification, testing, exploitation. Computational Economics, 51(4), 913-940.

Chaouachi, O., \& Douagi, F. W. B. M. (2014). Overreaction effect in the Tunisian stock market. Journal of Asian Business Strategy, 4(11), 134.

Chiao, C., \& Hueng, C. J. (2005). Overreaction effects independent of risk and characteristics: Evidence from the Japanese stock market. Japan and the World Economy, 17(4), 431-455. 
De Bondt, W. F., \& Thaler, R. (1985). Does the stock market overreact? The Journal of Finance, 40(3), 793-805.

De Bondt, W. F., \& Thaler, R. H. (1987). Further evidence on investor overreaction and stock market seasonality. The Journal of Finance, 42(3), 557-581.

Dizdarlar, H. I., \& Can, R. (2017). Aşırı tepki hipotezinin geçerliliğinin test edilmesi: Borsa İstanbul üzerine bir araştırma. Uluslararası iktisadi ve Idari Incelemeler Dergisi, 16. Uík Özel Sayısı, 815-832.

Doğukanlı, H., \& Ergün, B. (2011). Davranışsal finans etkin piyasalara karşı: Aşırı tepki hipotezinin iMKB'de araştırılması. Çukurova Üniversitesi Sosyal Bilimler Enstitüsü Dergisi, 20(1), 321-336.

Doğukanlı, H., Vural, G., \& Ergün, B. (2012). Aşırı tepki hipotezi: Farklı portföy formasyon ve test süreleri kullanarak iMKB' de bir araştırma. IMKB Dergisi, 13(49), 1-17.

Fama, E.F. (1970). Efficient capital markets: A review of theory and empirical work. The Journal of Finance, 25(2), 383417.

Fama, E.F. (1998). Market efficiency, long-term returns, and behavioral finance. Journal of Financial Economics, 49, 283306.

Fung, A. K. W. (1999). Overreaction in the Hong Kong stock market. Global Finance Journal, 10(2), 223-230.

Fung, A. K. W., \& Lam, K. (2004). Overreaction of index futures in Hong Kong. Journal of Empirical Finance, 11(3), 331351.

Gaunt, C. (2000). Overreaction in the Australian equity market: 1974-1997. Pacific-Basin Finance Journal, 8(3-4), 375398.

Huang, Y. S., Fu, T. W., \& Ke, M. C. (2001). Daily price limits and stock price behavior: Evidence from the Taiwan Stock Exchange. International Review of Economics ve Finance, 10(3), 263-288.

J.P.Morgan/Reuters (1996). RiskMetrics ${ }^{T M} \quad-\quad$ Technical document, $4^{\text {th }}$ ed. https://www.msci.com/documents/10199/5915b101-4206-4ba0-aee2-3449d5c7e95a (Erişim Tarihi, 28 Eylül 2018).

Jegadeesh, N. \& Titman, S. (1993). Returns to buying winners and selling losers: Implications for stock market efficiency. The Journal of Finance, 48(1), 65-91.

Hull, J.C. (2014). Options, futures, and other derivatives, New Jersey: Pearson Education, Inc.

Kahneman, D. \& Tversky, A. (1977). Intuitive prediction: Biases and corrective procedures, Technıcal report PTR-10427746. http://www.dtic.mil/dtic/tr/fulltext/u2/a047747.pdf (Erişim Tarihi, 1 Ekim 2018).

Karan, M. B., \& Tarım, Ş. A. (2001). IMKB'de hisse senedi getirilerinin aşırı tepkisi üzerine ampirik bir inceleme. $H U ̈$ iktisadi ve Idari Bilimler Fakültesi Dergisi, 19(1), 29-46.

Kashif, M., Saad, S., Chhapra, I. U., \& Ahmed, F. (2018). An empirical evidence of over reaction hypothesis on Karachi Stock Exchange (KSE). Asian Economic and Financial Review, 8(4), 449.

Klößner, S., Becker, M., \& Friedmann, R. (2012). Modeling and measuring intraday overreaction of stock prices. Journal of Banking and Finance, 36(4), 1152-1163.

Lasfer, M. A., Melnik, A., \& Thomas, D. C. (2003). Short-term reaction of stock markets in stressful circumstances. Journal of Banking and Finance, 27(10), 1959-1977.

Maher, D. \& Parikh, A. (2011). Short-term under/overreaction, anticipation or uncertainty avoidance? Evidence from India. Journal of International Financial Markets, Institutions \& Money, 21, 560-584.

Nam, K., Pyun, C. S., \& Avard, S. L. (2001). Asymmetric reverting behavior of short-horizon stock returns: An evidence of stock market overreaction. Journal of Banking and Finance, 25(4), 807-824.

Parikakis, G. S., \& Syriopoulos, T. (2008). Contrarian strategy and overreaction in foreign exchange markets. Research in International Business and Finance, 22(3), 319-324.

Polat, A., Türker, Y. \& Köse, H. (2016). Abnormal returns after large increases in stock prices. A comparison between Turkish Sport Index and Turkish banks. Business, Management and Economics Research, 2(11), 180-185.

Rezvanian, R., Krysiak, Z. \& Klaczynska, E. (2015). Equity market reaction to sharp price changes: Evidence from Poland. Scientific Annals of the "Alexandru loan Cuza" University of Iaşi Economic Sciences, 62(2), 169-190.

Schnusenberg, O., \& Madura, J. (2001). Do U.S. stock market indexes over- or underreact? The Journal of Financial Research, 24(2), 179-204.

Sevim, S., \& Yildiz, B. (2007). Overreaction hypothesis and an empirical work on the Istanbul Stock Exchange. Istanbul Stock Exchange Review, 9(35), 21-36. 
Spyrou, S., Kassimatis, K., \& Galariotis, E. (2007). Short-term overreaction, underreaction and efficient reaction: Evidence from the London Stock Exchange. Applied Financial Economics, 17(3), 221-235.

Tunçel, A. K. (2013). Aşırı tepki hipotezinin test edilmesi: Borsa İstanbul örneği. Uludağ Üniversitesi iktisadi ve idari bilimler Fakültesi Dergisi, 32(2), 113-122. 


\section{Ekler}

Ek 1.

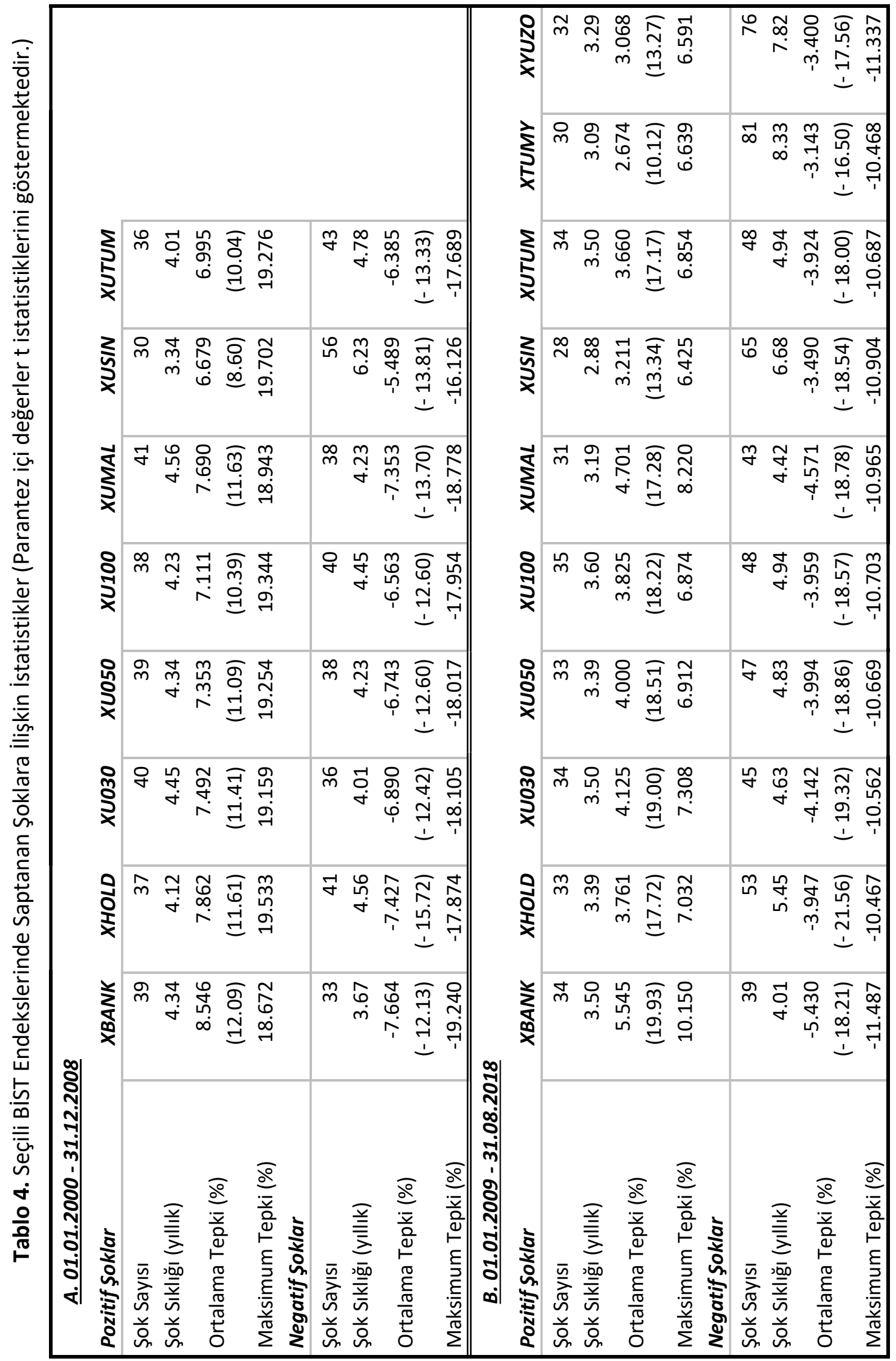


Ek 2.

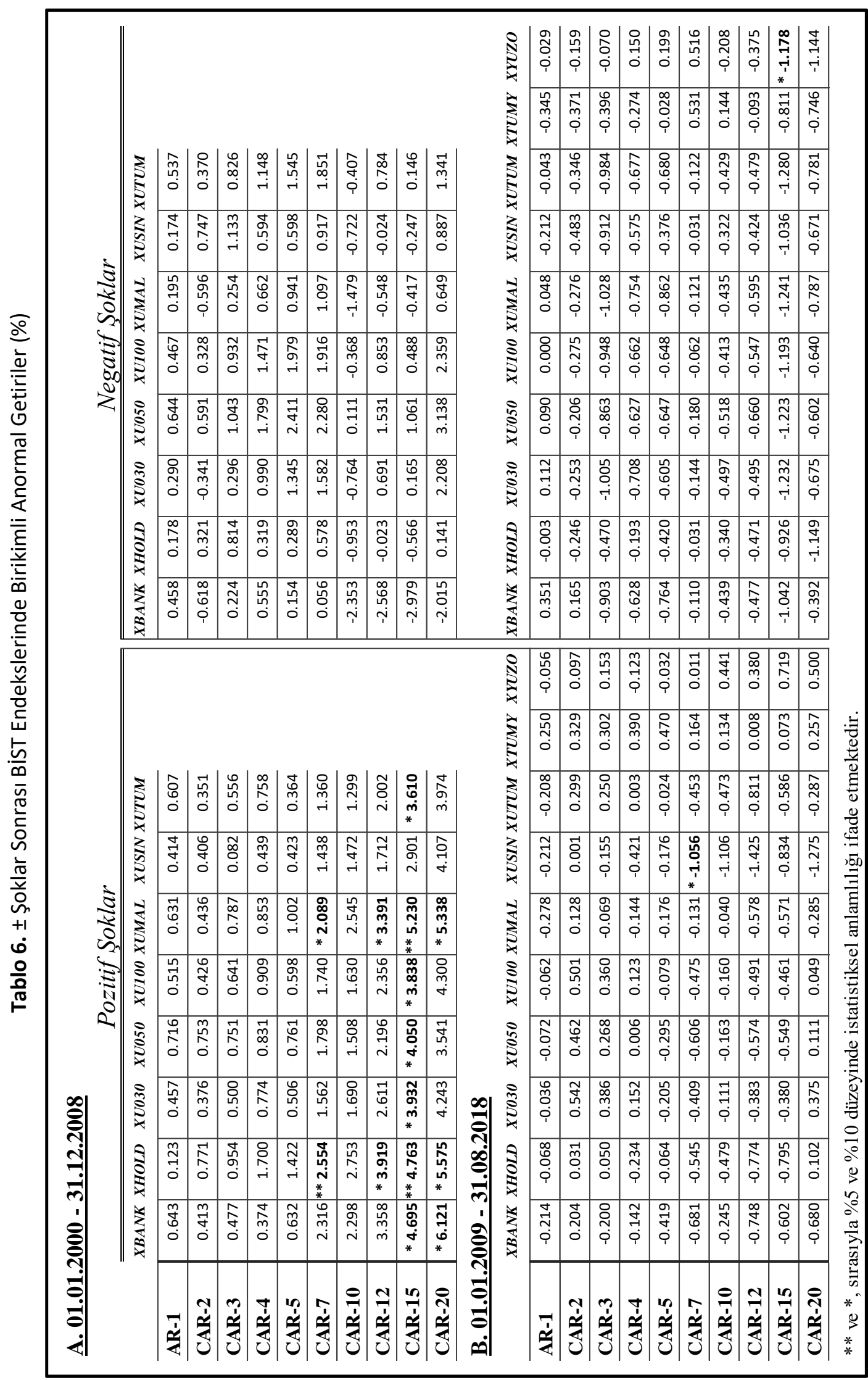


This Page Intentionally Left Blank 